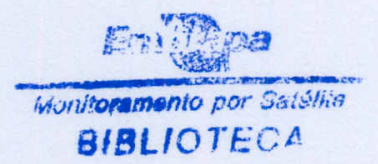

\title{
Small Farmers and Deforestation in Amazonia
}

Eduardo S. Brondizio, Anthony Cak, ${ }^{2}$ Marcellus M. Caldas, ${ }^{3}$ Carlos Mena, ${ }^{4.5}$ Richard Bilsborrow, ${ }^{6}$ Celia T. Futemma, ${ }^{7}$ Thomas Ludewigs, ${ }^{8}$ Emilio F. Moran, ${ }^{1}$ and Mateus Batistella ${ }^{9}$

This chapter discusses the relationship between small farmers' land use and deforestation, with particular attention paid to the past 30 years of Amazonian colonization in Brazil and Ecuador. Our analysis calls attention to common features uniting different social groups as small farmers (e.g., social identity, access to land and resources, technology, market, and credit), as well as the variability between small farmers in terms of time in the region (from native populations to recent colonists), contribution to regional deforestation, types of land use systems. At a regional level, small farmers contribute to the majority of deforestation events, but are responsible for only a fraction of the total deforested area in Amazonia. We discuss three misconceptions that have been used to define small farmers and their contribution to the regional economy, development, and deforestation: (1) small farmers have backward land use systems associated with low productivity and extensive deforestation and subsistence production, (2) small farmers contribute to Amazonian deforestation as much as large farmers, and (3) small farmers, particularly colonist farmers, follow an inexorable path of deforestation unless curbed by government action. We conclude the chapter discussing their growing regional importance and the need for more inclusive public policies concerning infrastructure and services and valorization of resources produced in rural areas of Amazonia.

\footnotetext{
${ }^{1}$ Department of Anthropology and Anthropological Center for Training and Research on Global Environmental Change, Indiana University, Bloomington, Indiana, USA.

${ }^{2}$ School of Public and Environmental Affairs and Anthropological Center for Training and Research on Global Environmental Change, Indiana University, Bloomington, Indiana, USA.
}

Amazonia and Global Change

Geophysical Monograph Series 186

Copyright 2009 by the American Geophysical Union 10.1029/2008GM000716
${ }^{3}$ Department of Geography, Kansas State University, Manhat$\tan$, Kansas, USA.

${ }^{4}$ Colegio de Ciencias Biologicas y Ambientales, Universidad San Francisco de Quito, Quito, Ecuador.

${ }^{5}$ Also at Department of Geography, University of North Carolina, Chapel Hill, North Carolina, USA.

${ }^{6}$ Biostatistics Department and Carolina Population Center. University of North Carolina, Chapel Hill, North Carolina, USA.

${ }^{7}$ Sorocaba Campus, Universidade Federal de São Carlos, São Paulo, Brazil

${ }^{8}$ Center for Sustainable Development, University of Brasilia, Brasilia, Brazil.

${ }^{9}$ Embrapa Monitoriamento por Satélite. Campinas, Brazil. 


\section{INTRODUCTION}

Small famers represent diverse social groups in Amazonia. (Oum use of the tem small famer in this chapter also inciudes social grours often designated under categories such as extractivists, colonists. agroextractivists, quilombolas. "haditional populations." family agriculture, collectors. fishers who practice agriculture, and other regional-cultural designations. In some cases, these categories involve a combination of collective and private use of resources. It also includes those who, old or new to the region. may not have formal land title or proof of use rights but who are directly involved with land use and resource management. For these reasons, in some instances we use the tem small holders interchangeably with small famers.) As such this encompassing term has been used broadly by researchers and policy makers to describe diverse populations with cultural, historic. demographic, and economic variability. In different ways they have been significant to the understanding of the dynamics of land use and deforestation. resource management and governance, and urbanization in the region. The history of small famers in Amazonia spans from historic populations (i.e. historical peasantry), usuallv humped together under the terms Caboclo or Ribereño, and migrant colonists dating back to colonization schemes of the late nineteenth century (e.g.. the region near Bragantina, in the northeastern part of the state of Pará. Brazil) to successive migrations of colonists throughout the twentieth century, particularly following govemment-sponsored projects and spontaneous migrations beginning in the late $1960 \mathrm{~s}$. Each of these successive waves of colonists amived in Amazonia from different areas. with different backgrounds and with different reasons for settling in the rogion. Even today. small famers continue to arrive to and migrate within the region: for example. the number of colonization settlements (for agrarian reform projects) in the region has reportedly tripled between 1994 and 2002. With over 500.000 families settled during this pertod Barreto et al. 2005; INCRA. 2000, 2002].

In the north region of Brazil. which enconpasses the area defined as Anazonia Legal, famly-based fams repiesent $85.4 \%$ of ail mal properties and cover $37.5 \%$ of the total area (ha) Gumatioli et al.. 2001]. This is comparable to other arus of Brazil. where. according to protminary data from the 2006 Brazilian Agricultumal Census [B 6 GE. 1998. 2009 a], in Bmail there are 5.204 .130 mal properties lestabetecimentos rumats covering an areat of 354.9 million ha, of which around 85\% repescni small holders testabelecimentoq rume fomiliares and occupy 107.8 million ha $(30.5 \%$ of the area of all rumal propedics

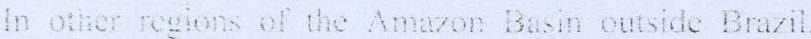

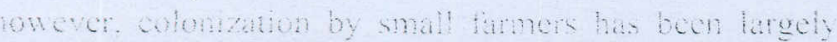

spontaneous. This is the case for example, in Northem Ecuadorian Amazonia (NEA), where only three small colonization projects were executed with limited success [Uquillas, 1984: Tamariz and Tillaverde. 1907: Pichon and Bilshorroir. 1999]. Thus. virtually all agricultural colonization in NEA has been unstructured. With the role of the govemment limited to passive granting of temporary or provisional land titles (certificados de posesion) to groups (precooperativas) of colonists (colonos) after they initially settle on the land in a certain area, with later granting of pemanent land titles (escrituras) [ Barshw, 1984]. (Colonist families pay small amounts for each, but nearly half of the fam families establishing the initial farms or fincas in the $1970 \mathrm{~s}$ and $1980 \mathrm{~s}$ never made the final payments for escrituras before the govermment land titling institute (Ecuadorian Institute of Agrarian Reform and Colonization (IERAC)) was eliminated in 1993 as part of public sector shrinking neoliberal policies.)

Much of the current debate about deforestation in Amazonia has been defined by contrasting land use and land cover change resulting from small- and large-scale faming activities [Walker et al., 2000; Aldrich et ai., 2006: OESP. 2008a. $2008 \mathrm{~b}$ ]. Yet. in aggregated terms (i.e.. at the state level). small farmers contribute to only a small portion of the areal extent of regional deforestation, although these smaller, deforested areas represent the majority of deforestation events in the region. The ambiguity in defining smail farmers, especially given their diverse backgrounds and motivations, and stereotypes about small-scale production systems as destructive and backward have played a role in the interpretation of their contribution to regional deforestation. For these reasons. this is a discussion which requires both an examination of figures and rates concerning land use change and considerations about the political ecology of resional development. Small-scale production systems are often lumped together as a single category and regarded as lacking technology and resembling abandoned fields while disregarded in terms of their productivity. contribution for food production, and agro-diversity. Furthemore. the lack of data on the contribution of small-scale production systems to the regional economy, to export. and food provisioning to urban centers has added to the lack of understanding about their regional miportance. In this context. some aspects of small farmers are rendered visible. While others invisible depending on the interlocutors [Brondirio, 2004: Costa. 2000

Although much remains to be learned about small-scale land use sstems in Amaronia since the 1980s, there has been a growing body of research shedding light on cortain segments of mall famors, espectall colonists. who represent an important group dring and cover change in the region

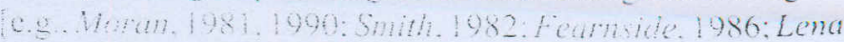

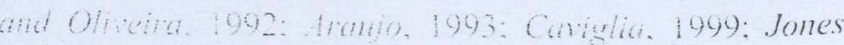


et al., 1995; Mc.Cracken et al., 1999, 2002; Brondizio et al. 2002; Moran et al., 2002; Walsh et al., 2002; Futemma and Brondizio, 2003: Caldas et al., 2007; Caldas. 2008; Tura and Costa, 2000; Murphy, 2001; Walker, 2003; Perz, 2001; Perz and Walker, 2002; Pichon et al., 2002; Castallenet and Jordan, 2002; Costa et al., 2006; Browder et al., 2008. among many others]. However, proportional to their demographic and economic importance, the contribution of small farmers to regional land use and food production continues to be invisible and stigmatized in the eyes of policy makers and some sectors of the regional population. While large-scale producers continue to be responsible for driving regional deforestation, small farmers are playing an ever-increasing role in the region through the formation of a complex socialenvironmental mosaic in the region. They connect rural and urban areas through social and economic networks [Padoch et al., 2008]; they are present in virtually all nonindigenous reserves and increasingly involved with regional conservation issues [Campos and Nepstad, 2006]; they are present across consolidated and new areas of agropastoral expansion [Costa, 2008; Moran et al., 2008]; they are the basis of a large economy involving river and forest resources [Smith et al., 2007; Brondizio, 2008]; their production systems include a gradient from very intensive, diverse and agronomically sophisticated to extensive, opportunistic and unproductive systems [Pinedo-Vasquez et al., 2002, 2003; Silva-Forsberg and Fearnside, 1997; Marquardt, 2008; Brondizio and Siqueira, 1997; Peroni et al., 2007; Smith et al., 1996]; they experience violence and conflict associated with land and resources [Simons, 2005]; they represent an expanding regional political movements [Campos, 2006]; and they serve as an emblem of the region's challenges to face climate change and prospects of sustainable development [Ozório de Almeida and Campari, 1995; Zarin et al., 2004; Brondizio and Moran, 2008].

This chapter discusses the relationship between small farmers (and small holders in general) and land use and deforestation, with particular attention paid to the past 30 years of Amazonian colonization. Our analysis calls attention to common features uniting different social groups as small farmers or small holders (e.g., social identity, access to land and resources, technology, market, and credit), as well as the variability between small farmers in terms of time in the region (from native populations to recent colonists) and other variables. These features have been important factors influencing land use behavior and deforestation in the region. We start by exploring different definitions of what constitutes small farmers in the region, based on categories such as historical groups, income, and farm size. (While our analysis includes as small farmers those who may be landless and work as sharecroppers, we do not examine the landless movement in the region as the complexity of the topic would require a full treatment in an article.) Following an examination of deforestation trajectories at the levels of the region, settlement (groups of farm lots), and individual farm lots, we focus our discussion on three misconceptions that have been used to define small farmers and their contribution to the regional economy, development, and deforestation: (1) small farmers have backward land use systems associated with low productivity and extensive deforestation and subsistence production. (2) small farmers contribute to Amazonian deforestation as much as large farmers, and (3) small farmers, particularly colonist farmers, follow an inexorable path of deforestation unless curbed by government action. We base our discussion on long-term research sites where coauthors have worked as part of the broader Large-Scale BiosphereAtmosphere (LBA) Experiment in Amazonia Program [Batistella and Moran, 2005; Costa et al., 2007; Batistella et al., 2008], including colonization settlements in the states of Pará, Acre, and Rondônia in Brazil, and colonization areas in the Ecuadorian Amazon (Figure 1). (Our constraint coverage of Brazil and Ecuador, based on LBA-related projects, leaves out important dynamics associated with small farmers in Bolivia, Peru, Colombia, and Venezuela which involves similar but also very different processes associated with public policies, economy and demography changes, production of illegal crops and drugs, and various forms of conflicts with large-scale logging concessions, large-scale farmers, oil companies, and government programs. However, we believe that most of the issues discussed here from the perspectives of Brazil and Ecuador are also relevant to other Amazonian countries.) Supporting data and statistical analysis, much of which have been published elsewhere, involve household and farm surveys, long-term ethnographic investigation, as well as multitemporal remote sensing and spatial analysis used to assess the contribution of farmers of different sizes to regional deforestation.

\section{DEFINING SMALL FARMERS IN AMAZÔNIA}

Although small farmers in Amazonia have remained analytically ill defined, there has been increasing attention to understanding sociocultural and political differences and similarities among different social groups and categories lumped together as the Amazonian peasantry [Brondizio, 2004; Adams et al., 2008]. The use of this term has greatly varied according to the interlocutor, purpose and political context, or region of interest. Three common typological definitions of small farmers and small holders have been employed in the region, based on (1) historical and social categories, (2) economic and income classes, or (3) landbased classes, such as farm size. Table 1 provides a com-

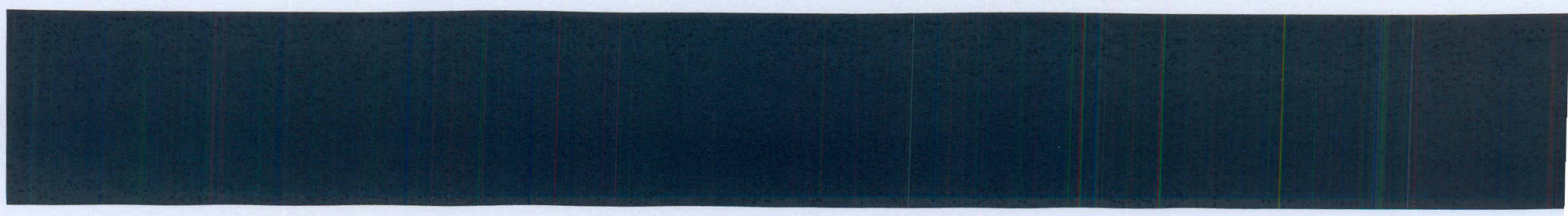




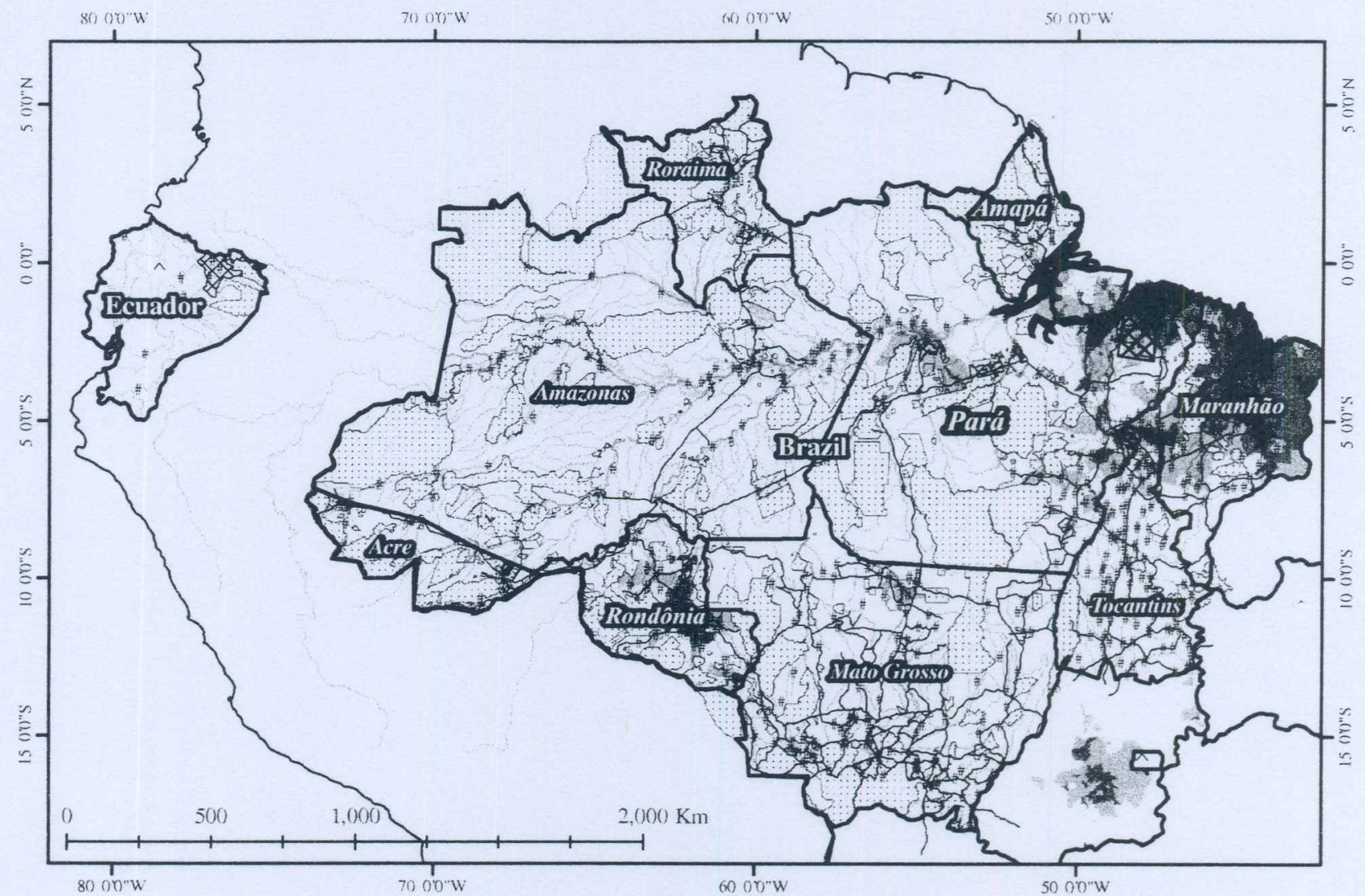

Legend

Brazilian Rural Population Density (persons $* \mathrm{~km}^{-2}$ )

$0.0-2.5$

10. $2.5-5.0$

$5.0-10.0$

$10.0-50.0$

$50.0-100.0$

$>100.0$

- Rivers

- Highways

\# Cities

State (apitals

$\wedge$ Country Capitals

$ख$ Study Areas

$Z 7$ Rural Settlements

Indigenous, Conservation, and State and lederal Protected Areas

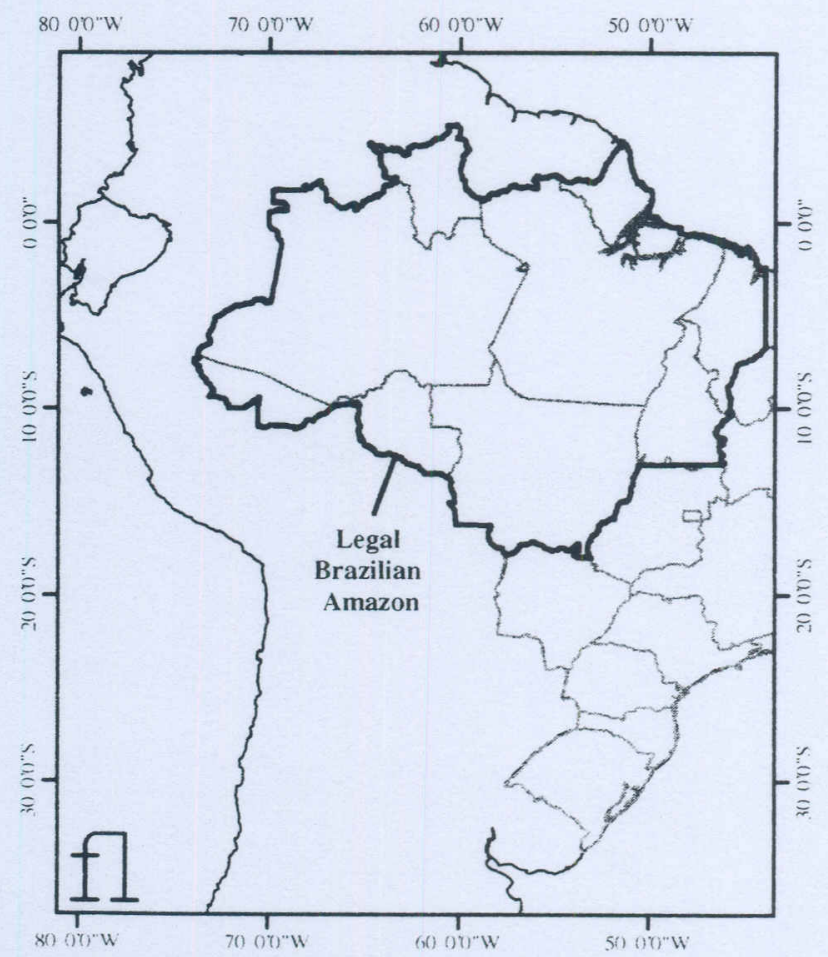

Figure 1. Rural population density (persons* $\mathrm{km}^{-2}$ ) by municipality, as counted by IBGE (2000 Census, available at http:/ www.sidra.ibge gov.br/ed/defaulted2000.asp? $0=2 \& \mathrm{i}=\mathrm{P}$ ) for the states bordering the Legal Brazilian Amazon: location of study areas in the Ecuadorian and Brazilian Amazon; and location of rural settlements, protected areas, rivers, highways, capitals, and cities. 
parative illustration of different typologies to characterize groups of farms and farmers based on economic and farmsize criteria. An alternative categorization, based on the organization of farm labor and broad class structure, has been proposed by the Brazilian National Institute of Colonization and Agrarian Reform (INCRA) [INCRA/FAO, 2000] and defines family-based, in contrast to patron-based (i.e., proxy for large farmers) agriculture and farm operations. Family agriculture, in this case, is defined by (1) the main decision maker as the producer, (2) the number of paid laborers as lower or equal to the amount of family labor, and (3) the size of property as lower or equal to the regional pattern [Guanziroli et al., 2001]. (Family labor includes individuals who are 14 years old or older; individuals younger than 14 years old are considered but to be part-time ( $50 \%$ ) workers. Each region in Brazil maintains a different maximum property size criteria that is established by the Brazilian Federal government; thus the size of family properties cannot exceed regional requirements. In the case of the north region, the maximum property size is 1122 ha [Guanziroli et al., 2001].)

\subsection{Historical Categories}

Historical and social categories have generally been used to contrast groups related to the colonial history of the region with recent migrants, but has been less clear about those in between. For example, a variety of social groups have been lumped together under the term Caboclo, a term that has been used to describe nonindigenous historical or "traditional" populations and, until recently, has carried a strong stigma and negative connotation [Brondizio, 2004, 2008; Adams et al., 2008; Hiraoka, 1992]. During the past decade, the concept of "traditional population" to refer to historical peasant groups undertaking small-scale, forest-based land use systems and often occupying areas of interest for forest conservation has become an increasingly popular and significant legal instrument to guarantee land rights to numerous communities and families of small holders characterized as small farmers, extractivists, quilombolas, fishers, and/or a number of other historical and regional denominations. It, in turn, has also become a marker of cultural identity and ancestry throughout the region. However, and arguably, the

Table 1. Property Size Class Categories by Income and Area From Fundo Constitucional de Financiamento do Norte Program (FNO), Brazilian National Institute of Colonization and Agrarian Reform (INCRA), and Brazilian Institute of Geography and Statistics (IBGE) for Brazil and for the Northern Ecuadorian Amazon ${ }^{a}$

\begin{tabular}{|c|c|c|c|c|c|c|c|}
\hline \multicolumn{2}{|c|}{$\begin{array}{l}\text { Income in the Northern } \\
\text { Ecuadorian Amazon }\end{array}$} & \multicolumn{2}{|c|}{ FNO Size Classes } & \multicolumn{2}{|c|}{ INCRA Size Classes } & \multicolumn{2}{|c|}{ IBGE Size Classes } \\
\hline \multirow[b]{2}{*}{$\begin{array}{c}\text { Farm Size } \\
\text { Classes } \\
\text { (ha) }\end{array}$} & \multirow[b]{2}{*}{$\begin{array}{l}\text { Mean } \\
\text { Household } \\
\text { Income } \\
\text { (US\$) }\end{array}$} & PRONAF & FNO & \multirow[b]{2}{*}{$\begin{array}{c}\text { Total Area } \\
\text { (ha) }\end{array}$} & \multirow[b]{2}{*}{$\begin{array}{l}\text { Total Income } \\
\text { (RS) }\end{array}$} & \multirow[b]{2}{*}{ Total Area (ha) } & \multirow[b]{2}{*}{$\begin{array}{c}\text { Total Area of } \\
\text { Settlement } \\
\text { (ha) }\end{array}$} \\
\hline & & $\begin{array}{c}\text { Gross Income } \\
\text { (RS (\% From Farming)) }\end{array}$ & Gross Income (R\$) & & & & \\
\hline $1-1.9$ & 482.2 & $<2,000(30 \%)$ & 80,000 & $<5$ & $<0$ & $<1$ & \\
\hline $2-4.9$ & 778.7 & $2,000-14,000(60 \%)$ & $80,000-160,000$ & $5-20$ & $0-3,000$ & $1-2$ & \\
\hline $5-9.9$ & $1,017.2$ & $14,000-40,000(70 \%)$ & $160,000-1,000,000$ & $20-50$ & $3,000-8,000$ & $2-5$ & \\
\hline $10-19.9$ & 995.8 & $40,000-60,000(80 \%)$ & $>1,000,000$ & $50-100$ & $8,000-15,000$ & $5-10$ & $<10$ \\
\hline $20-29.9$ & $1,275.4$ & & & $100-" 15$ & $15,000-27,500$ & $10-20$ & $10-100$ \\
\hline $30-39.9$ & $1,402.1$ & & & Regional & $>27,500$ & $20-50$ & $100-200$ \\
\hline $40-49.9$ & $1,640.6$ & & & Modules" & & $50-100$ & $200-500$ \\
\hline $50-59.9$ & $2,161.7$ & & & & & $100-200$ & $500-2,000$ \\
\hline $60-90$ & $4,013.7$ & & & & & $200-500$ & \\
\hline$>90$ & $2,126.6$ & & & & & $500-1,000$ & $>2,000$ \\
\hline & & & & & & $1,000-2,000$ & \\
\hline & & & & & & $2,000-5,000$ & \\
\hline & & & & & & $5,000-10,000$ & \\
\hline & & & & & & $\begin{array}{r}10,000-100,000 \\
>100,000\end{array}$ & \\
\hline
\end{tabular}

\footnotetext{
${ }^{a}$ Northern Ecuadorian Amazon data are from Bilsborrow et al. [2004]. Note that columns are independent of each other.
} 


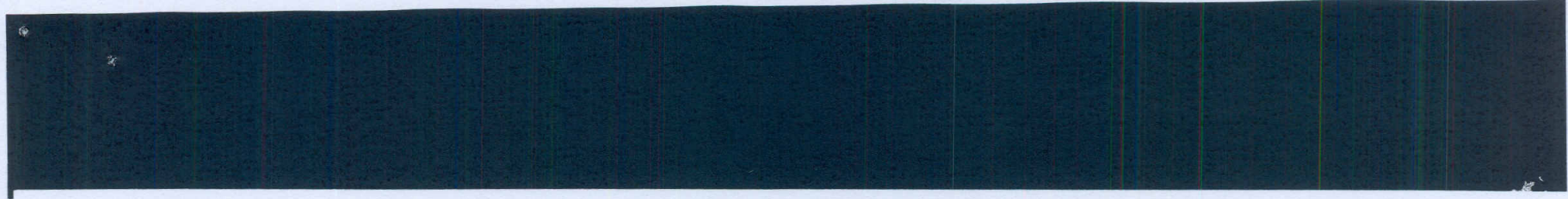

academic-political use of the term "traditional populations," when associated with small-scale land use systems, has created more ambiguity and problems than it has resolved; this topic, while relevant to discussion of Amazonian small farmers and deforestation, is beyond the scope of this paper [DeCastro et al., 2006; Barreto-Filho, 2006].

Perhaps even more encompassing is the term colonist, or migrant farmer, which has been commonly used in the land use literature to describe more recent migrant groups, whose arrival often has been spontaneous or through planned government settlement projects [Brondizio, 2004; Caldas et al., 2007]. In the Brazilian Amazon, for example, the history of planned settlement and government-sponsored colonization dates back to the late nineteenth century with the formation of settlements along the Belém-Bragantina railroad, intended to serve as food production areas for a region dedicated to the expansion of the extractivist rubber economy. Following the decline of rubber as a significant export commodity around 1910, small waves of migration have influenced the occupation of the region around cities such as Santarém and Belém, and to smaller extent, every other state in the region, though this migration was largely sparse compared to later waves of migration.

Beginning in the 1930s, Japanese colonists in the state of Pará spearheaded a new wave of small-scale land use production systems, and subsequently, Japanese settlers and their descendants experimented new forms of intensive small-scale land use systems. Their experimentation with various crops and means of cultivation led to their status, by the 1960 s, as one of the top world producers of black pepper. Even with a sharp decline in black pepper production during the late 1960s as a result from both Fusarium disease and decreasing world market prices, Japanese colonists, such as the community of Tome-Açu continued to innovate by ushering in new forms of intensive agroforestry systems that focused on high-value fruit production, coupled with fruit processing plants for export. Cooperatives such as Cooperativa Agrícola Mista de Tomé Açu (CAMTA) have shown the potential of intensive small-scale production coupled with transformation industries and export networks to aggregate value to local production [Yamada, 1999]. Besides black pepper and native fruits, in the Lower Amazon, the Japanese community also cultivated jute (Corchorus capsularis), a vegetal fiber that was brought to Amazonia by a Japanese agronomist. Jute production in Amazonia quickly grew, and Amazonia became one of the main international producers of this crop for more than 40 years until the end of the 1970s when jute production in Brazil started to decline due to competition from Asian producers [Gentil, 1988; Winkerprins, 2006]. Following the decline in production, most of the Japanese families left the lower Amazon region and migrated to other regions of Brazil, mainly to capital cities, though jute still continues to be cultivated by local populations.

While some regions of the Amazon, such as around Santarem in the lower Amazon, experienced significant waves of migration during the 1950 s and 1960 s, particularly from the northeast of Brazil, the rate of migration of small farmers dramatically increased after 1970 as a result of government-sponsored programs that selected families on the basis of origin, age, and composition to settle in various parts of Amazonia [Moran, 1981]. This process was particularly marked along road systems that were constructed as part of different national integration and colonization schemes, including areas along the Transamazon Highway in the state of Pará, in the state of Rondônia, and later in the state of Acre; these changes were dramatic, in some cases, doubling the population moving to rural areas on a yearly basis. However, a significant part of these populations that moved to rural areas and colonization settlements in the 1970 s soon became disregarded and abandoned without adequate support, passable roads, and service infrastructure in rural areas. Many ended up moving to urban areas and emerging nearby urban centers [Browder and Godfrey, 1997], eventually leading to an increased process of lot turnover that has characterized much of the failure and disregard of colonization areas of the region and the paradox of land aggregation in areas of agrarian reform [Ludewigs et al., 2009; Campari, 2002].

As in the aforementioned frontier areas of Brazilian Amazonia, in NEA, land clearing (deforestation) and land use change by migrant farmers generally followed the construction of infrastructure (especially roads) laid out for oil extraction. Oil companies, starting in the early 1970 s, built roads to lay pipelines to extract petroleum. Families seeking land then poured into the region, mostly from the Sierra or Highlands regions, which were characterized by considerable landlessness and land concentration along the roads. Farms of about 50 ha $(250$ by $2000 \mathrm{~m}$ ) were established along roads. When all the land was taken in an area or sector along the primary roads, the next wave of settler families then settled behind the first settlers on farms parallel to the roads, on so-called lineas (generally $2 \mathrm{~km}$ ) behind the farms along the roads. Eventually, farms were established and ratified by the IERAC commonly up to the fifth or 6 th linea, though some have reached a distance of up to the 14th linea. Continuing through today, the oil industry and related services have remained as a pull factor attracting migrants to the NEA

\subsection{Economic Categories}

Economic and income categories also have been used to differentiate small farmers from larger landowners involved in regional agropastoral economies. (It is important to note 
that social movements, such as those represented by Pesagri, rural labor unions, "Grito da Terra," and a variety of local and regional organizations, tend to use historical class distinction to differentiate patronage (larger landowners, local elites) and the rural labor force (including small land holders). Some of the strongest social movements, however, are associated with ancestry and historical land use systems, such as the case of the rubber tappers movement, which emerged under the leadership of rural union leader Chico Mendes but evolved to represent a way of life and economy based on the historical association between farmer, or extractivist, and forest. The church, particularly through movements associated with pastoral committees for land, has played an important role contributing to the organization of small farmers in cooperatives and producers' associations. The region today houses a variety of producers' associations and confederations aiming at uniting different sectors of rural populations.) Overall, $72.3 \%$ of farms in Brazilian Amazonia have a total income of less than US\$1500, 22\% are between US\$1500 and US $\$ 4000$, and less than $2 \%$ is above US\$7500 [INCRA] $F A O, 2000]$ (based on exchange rate of US\$1/R\$2). In the Ecuadorian Amazon, mean income ranges from US\$482 (farm lots $<2$ ha) to US $\$ 4000$ (farm lots $60-90$ ha).

In particular, credit programs have typically defined producers on the basis of income as a proxy for assigning different farmers and group of farmers to different credit programs (Table 1). For example, the Fundo Constitucional de Financiamento do Norte program (FNO), controlled by the Amazonian Bank (BASA), defines categories of farmers according to income, despite using a questionable range of income groups to represent, or potentially misrepresent, the reality of rural households in the region and the way different groups benefit from credit. Income, specifically gross annual production (GAP), is used to aggregate farmers into four categories: (1) minifarmers, (2) small-scale farmers, (3) medium-seale farmers, and (4) large farmers. However, the GAP used to define each category seems distant from the reality of most families in rural areas. Mini-scale farmers, for instance, have a GAP corresponding to less than US\$13,800 per year, while small-scale farmers are defined between US $\$ 13,800$ and US\$27,600 per year. Medium-scale farmers are defined between US\$27,600 and US\$172,400 per year and largescale above that $[B A S A, 2002,2004]$. According to INCRA and Brazilian Institute of Geography and Statistics (IBGE) data [INCRA/FAO, 2000], the average family income (renda total) for the North region is around R\$2904 (approximately US\$1540), while the farm income (renda do estabelecimento) averages R\$1935 (approximately US\$1025). For "large" owners (patronagem), income is R\$11.883 and R\$9691, respectively (approximately US\$6300 and US\$5137). It is not surprising, then. that BASA has characterized the distribu- tion of FNO credit as overwhelmingly beneficial for miniand small-scale farmers ( $62 \%$ of these categories receiving funds), while in reality, groups receiving credit also include medium and large farmers.

Field surveys [Brondizio, 2004] indicate that the rate of credit acquisition by colonists varies significantly according to the availability and conditions of government credit programs. However, over the course of 30 years of settlement along the Transamazon Highway, we found that around $56 \%$ of households interviewed received credit at least once. Annual rate of acquisition, however, is less than $10 \%$. These figures are significantly lower for the Santarem-Belterra region. A recent survey $(2007 / 2008)$ of riverine farmers in the Amazon estuary shows that over $90 \%$ of farmers have never received credit for land use activities, though they represent the most important sector producing açai fruit for regional and external markets [Brondizio, 2009]. For all of these regions, however, since 2006 , there has been a slight increase in small credit loans, typically less than US\$500, from the FNO program. These loans have been given for activities such as weeding or maintenance of existing fields. However, these programs have lacked any sort of assistance or monitoring and have functioned more as small aid grants than an agricultural credit involving monitoring and assistance.

\subsection{Land Holding and Land Clearing Categories}

Farm size categories have been used in a variety of ways to represent groups of farmers. For categorizing small farmers, the range of farm sizes varies widely in different parts of the region and should thus be viewed in relative terms. While peri-urban lots and areas with a long history of settlement have tended to contain farm lots varying from 1 to 50 ha, lots granted within colonization areas generally have ranged from 50 and 150 ha, though in some cases have included lots larger than 400 ha usually designated as "glebas." Overall, the average area of family-based farms in the Brazilian Amazon is 57 ha, while the average area of large farms is 1009 ha (compared to the Brazilian average of 26 and 433 ha, respectively) [Guanziroli et al., 2001]. In some cases, however, families settled in extractive reserves may have access to significant larger areas usually combining private and commonly held land.

Sizes of agricultural clearings, derived from spatial assessments of deforestation, such as Instituto Nacional de Pesquisas Espaciais, São Paulo, Brazil's (INPE's) Programa de Cálculo do Desflorestamento da Amazônia (PRODES) project [INPE/PRODES, 2003], have also been used as a proxy to define categories of farmers. Although summary data from INPE-PRODES aggregates deforested areas from 1 to 15 ha and from 15 to 50 ha, these intervals have been 
used, by the media for instance, to describe clearing done by "small farmers." Field data, however, have indicated that most small farmers tend to deforest areas (i.e., annual deforestation events) smaller than 5 ha and, on average, lack the capacity (i.e., labor and capital) to clear larger areas, usually clearing 0.5 to 3 ha per year [Brondizio et al., 2002]. Yet for the purpose of our analysis, particularly at a regional, aggregated level, size of clearings provides an acceptable comparative indicator to understand the composition of events making up regional deforestation. In lieu of better data, these assessments provide a proxy to compare the contribution of "small" and "large" farmers to regional deforestation.

\section{METHODS}

Our analysis is based on field observations and bibliographic data from different areas of the Amazon $\mathrm{Ba}$ sin, including colonization settlements along the BR-230 Transamazon Highway (Altamira, Brasil Novo, Medicilândia, Uruará) and the BR-163 (Santarem, Belterra); rural communities in the Amazon estuary (Ponta de Pedras) in the state of Pará; colonization areas in the Brazilian states of Acre (Porto Acre) and Rondonia (Machadinho, Anari); and colonization areas in NEA. Besides variation in soil quality and forest types, these sites have different colonization and demographic histories. Our analysis also includes field observations and bibliography concerning small holders living within extractivist reserves [such as the Tapajós National Forest (Flona Tapajós) near Santarém] and peri-urban farmers such as around Altamira and Santarém, where we have developed field research

The Altamira, Brasil Novo, Medicilândia, and Uruará study sites were part of a large colonization and settlement program enacted by the INCRA, beginning in the early 1970 s with the opening of the Transamazon Highway. In the Altamira, Brasil Novo, and Medicilândia study areas, we built upon studies that comprised of 3718 farm-lots along the Transamazon Highway and feeder roads (travessões) using a stratified random sample of 402 and 399 farms during 1997 and 2005, respectively, with a subsample of 171 in 2001. These studies include detailed sociodemographic and economic surveys of households stratified by time in the region. The research team collected a set of data related to land use allocation over time, labor, technology, market. credit, and use of forest resources, and a set related to family reproductive and migratory histories, socioeconomic and labor arrangements. On average, farm activities are quite diverse in Altamira, with farmers producing annual crops $(50 \%$ of studied properties), cacao and other perennials (35\%), cattle $(95 \%)$, and horticultural activities $(40 \%)$ [Siqueira et al., 2003; Moran et al., 2005; Vanwev et al., 2007; Brondizio et al., 2002; McCracken et al., 1999; Deadman et al., 2004; Siqueira et al., 2007; Lim et al., 2002; Evans et al., 2001]. For the Uruara study area, we built upon a study of small properties, typically one or more 100 ha lots (the average property size in the sample is $133 \mathrm{ha}$ ), located an appreciable distance (approximately $18 \mathrm{~km}$ ) from the Transamazon Highway. This study used household surveys to analyze market access and land process (i.e., distance from the main highway), household dependency (i.e., the number of individuals not engaged in farm work, namely, children, women, and elderly individuals), family household structure (i.e., counts of individuals in age-sex cohorts), amount of hired labor employed (in person-days or diárias), age of the household head in years, access and use of agricultural credit for farm activities, and length of time (in years) the household has been living on the property. Overall, farming systems are highly diversified across annuals crops ( $53 \%$ of the studied properties adopted some type of annual system, such as rice, beans, and corn), perennial crops ( $72 \%$ of the studied properties adopted some type of perennial system, including coffee, cocoa, and pepper), and pasture ( $95 \%$ of the studied properties raised cattle). Pasture is the dominant land use and averages about 23 ha per property, as is common for Amazonian colonists [see Walker, 2003].

For the Santarem and Belterra sites, we studied 5953 farm-lots using a stratified random sample of 244 and 401 in 2001 and 2003, respectively, and community-level studies $(n=409)$ [D'Antona et al., 2008; Vanwey et al., 2007]. Santarém region had until recently the largest proportion of secondary vegetation, and lower adoption of perennial crops $(36 \%)$ and cattle ranching $(46 \%)$, but $77 \%$ of the farms produced annual crops.

Located approximately $400 \mathrm{~km}$ from the state capital Porto Velho, the research sites of Machadinho and Vale do Anari have different histories and settlement designs. Comparative studies of these sites included longitudinal socioeconomic surveys, settlement level institutional analysis, ecological field studies and vegetation inventories, multitemporal remote sensing, and landscape fragmentation analysis $[\mathrm{Ba}$ tistella, 2001]. The Machadinho settlement started with an area of $2090 \mathrm{~km}^{2}$ with 2934 plots designated to receive small farmer colonists from other states. In 1988, Machadinho became a municipality and expanded to incorporate four other settlements and small towns. In 1989, the rural population represented two thirds of Machadinho's total population. Less than 10 years later, the rural population diminished to one third of the total. Vale do Anari started as a spontaneous settlement, but was later established as a planned colonization area by INCRA in the early 1980s and, in 1994, became a municipality. As other colonization areas, it lacked assistance, urban infrastructure, or administrative autonomy. 
These dynamics led the two settlements to have different institutional arrangements, rules of forest use, and outcomes in terms of the interactions between the colonists and the environment [Batistella et al., 2003]. The majority of the colonists in this area came from the south of Brazil, mainly the State of Paraná, bringing with them specific production systems. The result, in terms of spatial organization of farming plots, is a mosaic of pasturelands, perennial crops, mainly coffee and cocoa, and annual crops (corn, rice, and beans). Land cover characteristics are also defined by different stages of land occupation and secondary succession contrasting with the native rain forest [Batistella et al., 2003].

For the Amazon estuary site in the municipality of Ponta de Pedras (State of Pará), we have conducted longitudinal ethnography and surveys of households $(n=143)$ and communities $(n=6)$ differentiated by economic and institutional histories and land tenure [Brondizio, 2008]. Estuarine communities studied here have over $95 \%$ adoption of açaí agroforestry and a decreasing rate of annual crops such as manioc, and abandonment of pasture areas and mechanized agriculture implemented during the 1970 s and 1980 s by external development projects.

The Humaitá study site was part of the Humaitá settlement in the State of Acre that was implemented in 1981 to subdivide rubber extraction estate into 948 lots. This site was surveyed in 2003 and 2004 ( $n=98$ farms) [Ludewigs, 2006]. The Acre site resembles the Transamazon Highway study region, in that, it has experienced a high rate of adoption of pasture $(95 \%)$ but lower rates of perennial (42\%) and annual (48\%) crops

The NEA study site is located in a settlement area that also has been considered an area of high biological and cultural diversity [Myers, 1990; Orme et al., 2005]. Similar to many settlements in Brazilian Amazonia, Ecuadorian farms approved by the IERAC were mostly homogenous in size, each approximately 50 ha, and were rapidly acquired, in part, to circumvent the creation of two large national parks and protected areas in the region and the provision of communal land to indigenous communities, most of whom had lived in the region for centuries in a seminomadic situation. This meant that the continuation of in-migration after 1990 , when most of the nontitled areas had already been occupied by colonist families, led to a process of farm subdivision of the original fincas, resulting in even smaller farms. Thus, the average farm size decreased from 46.5 ha in 1990 to only 25.5 ha in 1999 [Bilsborrow et al., 2004]. We used data from longitudinal household surveys administered in 1990 and 1999. The survey is based on a statistically representative probability sample of 470 farm plots selected in 1990 using two-stage sampling, with lists of settlement areas with the number of farms and the total area in each constituting the sample frame. In the first stage, 64 cooperatives or areas of colonization (sectors) were selected with probabilities proportional to size. In the second stage, the number of farms randomly selected from each sample sector was based on the size of the sector (called in-sampling, probabilities proportional to estimated size). Questionnaires were administered to each household head and spouse covering, together, their economic situation in the previous residence, land tenure, and acquisition in the NEA, land use, agricultural production and technology, work on and off the farm, credit, household composition, migration, fertility, health, dwelling quality, household assets, contacts with local communities for services, etc. The number of households increased greatly between 1990 and 1999, due to both subdivisions among heirs and sales to new in-migrants continuing to come to the region in search of land.

To derive deforestation estimates at the state, regional, and farm levels for each of these areas, we used multitemporal remote sensing data and analyses. For settlement and farm level analysis, research groups provided estimates for their respective study area. Data for Brazilian Amazonia was based on 2003 PRODES data from INPE and was collected for the states of Acre, Pará, and Rondônia [INPE/PRODES, 2003], all of which have relatively large populations of small farmers. PRODES data was aggregated into four classes: deforestation, forest, water, and other (e.g., clouds and older cleared areas) and analyzed using ArcGIS (Environmental Systems Research Institute (ESRI), Redlands, CA) to assess the number and size of clearings (i.e., polygons of deforestation in the PRODES data) and the amount and percent of deforested area (i.e., area of each clearing event).

Each of the cases reported in this chapter benefit from a long list of publications, part of which is cited here. It is not our intention to develop new statistical analysis of primary data, but to refer to published work as we seek to understand similarities and differences among small farmers across the region.

\section{EXAMINING FACTORS AND TEMPORAL PATTERNS ASSOCIATED WITH SMALL FARMER DEFORESTATION IN AMAZONIA}

\subsection{Size of Clearings as Indicator of Deforestation at State and Regional Levels}

Comparing state level deforestation in Brazil for 2003 using data on size of clearings [INPE-PRODES, 2003], we found that for the states of Pará, Acre, and Rondônia, small clearings (e.g., up to 20 ha) are the most frequent size classes of deforestation, comprising approximately $88.1 \%$ of the total number of forest clearings in Acre, $74.0 \%$ of the total

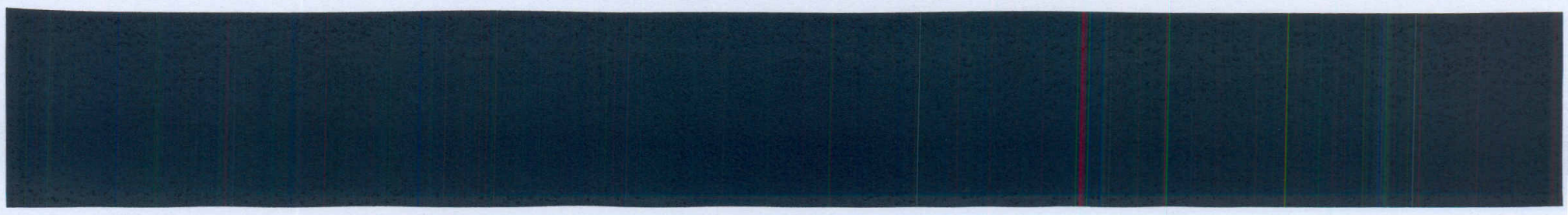


number of clearings in Pará, and $73.2 \%$ of the total number of clearings in Rondonia. However, when considering the area deforested, we found that these same clearings contributed only $7.6 \%, 3.2 \%$, and $2.1 \%$, respectively, of the total deforestation for these states (Table 2). The larger clearings (i.e., greater than 2000 ha) comprised only approximately $0.10 \%, 0.47 \%$, and $0.40 \%$ of the total number/events of clearings in Acre, Pará, and Rondônia, respectively, but they accounted for $86.0 \%, 91.2 \%$, and $94.5 \%$ of the total deforested area, respectively. This result indicates that large clearings are the most predominant features of deforestation in each state. The inclusion of the state of Mato Grosso would certainly reinforce this pattern. These large clearings may consist of clearings of large areas on one or several adjacent properties creating one large area of deforestation. Across all three Brazilian states, we found that the total number of clearings below 20 ha contributed to a small proportion of the total area deforested. Acre had the largest number of small clearings (e.g., number of clearings less than 20 ha), which contributed to a larger amount of cleared area relative to Pará and Rondônia for similar clearing size classes. However, both Pará and Rondônia had a greater number of large clearings (e.g., greater than 2000 ha), which contributed to an overall larger, cleared area than in Acre.

While the contribution of small farmers to total regional deforestation may be relatively small, their contribution varies across states and within states and, as such, has different environmental consequences. The large number of clearing events, albeit relatively small in total area, has important implications for environmental changes, depending on their landscape context. In colonization areas for instance, settlement design and institutional arrangement contribute to the cumulative spatial pattern of forest cover and distribution of deforestation [Batistella, 2001; Batistella et al., 2003]. Depending on the property design of particular settlements, isolated small clearings can add up to represent large-scale environmental change. Furthermore, the diversity of land use systems and the role and intensity of external pressures makes it difficult to generalize the contribution of small farmers to the regional environment as a whole. In many cases, one finds productive interactions between the agro-ecology and the spatial-temporal arrangements of local production systems and their landscapes. At the same token, under particular contexts, they can impact wildlife habitat and population, contribute to resource depletion and soil erosion, and the spread of accidental fires to forests [Toniolo, 2004; Sorrensen, 2004].

According to the FAO, Ecuador had the highest rate of deforestation in South America in the last two decades [FAO, 2001, 2005], and within Ecuador, the NEA is the second most active deforestation front after the Choco region in the coastal 
province of Esmeraldas [Sierra, 2000]. Although deforestation rates are decreasing in NEA, from $2.5 \%$ cleared per year between 1986 and 1996 and $1.8 \%$ per annum in 19962002, these rates are still comparably high [Mena et al., 2006b]. While the most important agent of deforestation in the Ecuadorian Amazon has been the small farmer, and smallholding agriculture has been the main process affecting forests, the impact of other processes on forest ecosystems in NEA should not be overlooked; for example, two large agro-industrial projects, starting in 1973 when two corporations were given land titles to establish African palm plantations, have deforested a combined area of roughly 20,000 ha [Santos and Messina, 2008], the equivalent of 400 farms or about $1.8 \%$ of the colonization area [colonization area calculated from the areas of precooperatives of settlement in the Aguarico Zone and Coca Zone of Instituto Ecuatoriana de Reforma Agraria y Colonización (IERAC)] in the NEA.

When comparing deforestation across colonization settlements in different parts of the region, one finds that interregional differences in forest clearing rates are closely related to age and history of the settlement (Figure 2). For example, the Santarém-Belterra region already experienced deforestation before the 1970 s, but experienced high rates of conversion of forests to agropastoral uses during the period between 1973 and 1979 , followed by widespread secondary regrowth. After this period, migration to the area and rates of forest conversion stayed relatively lower until recent expansion of soybeans, starting around 1999. In Altamira, one observes pulses of deforestation coinciding with rates of migration and lot occupation (1973-1979) followed by periods of decline (1985-1993) and subsequent expansion of cattle ranching and deforestation such as during the 1997--2003 periods. The Acre site experienced spikes in deforestation both during the late 1980s and after the mid-1990s. In all cases, it is important to observe the variability of deforestation rates among farm lots within the same settlement. In the Amazon estuary, however, one sees an opposite trend in deforestation associated with the intensification of small-scale agroforestry systems by riverine farmers and the existence of a diversified forest and river-based resource economies closely engaged with regional and global markets [PinedoVasquez and Padoch, 2009; Pinedo-Vasquez et al., 2001: Smith et al., 2007; Brondizio, 2008]. For more than two decades, the estuary has been undergoing a "forest transition" associated with the decline of annual crops and the rise of forest products, a process which has simultaneously led to land use intensification and population increase in urban and rural areas [Winklerprins, 2002; Padoch et al., 2008; Costa and Brondizio, 2009].

\subsection{Farm Size as a Variable}

Farm size, in particular, has played an important role in the land use allocation strategies of farmers and the distribution of deforestation events over time. (Classes of private property size are controversially treated across the literature and within government agencies and programs. Several levels of details and typologies are available and informed our organization of size and categories. We consulted websites and publications from government agencies such as the
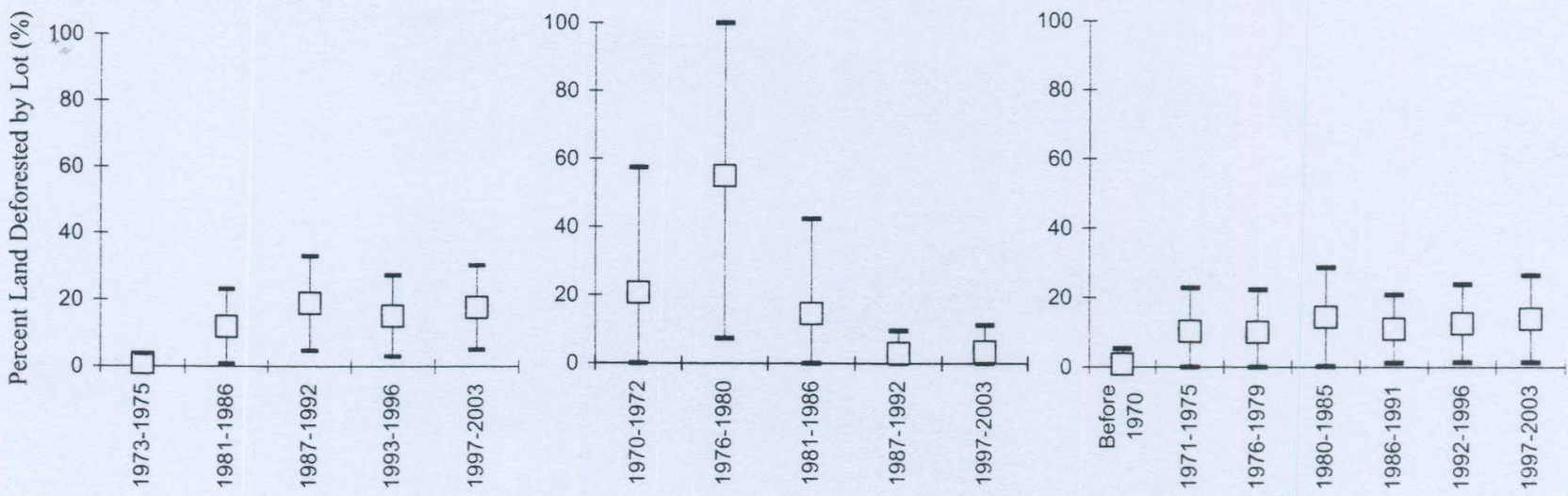

Time Period

Figure 2. Percentage of land $(\%)$ deforested by farm property lots in agricultural settlements in Porto Acre, Santarém, and Altamira, Brazil (boxes correspond to average values, comprehended within quartiles for each time period). 
IBGE and INCRA, government programs such as FNO, and publications from the Brazilian nongovernment organization IMAZON.) While the percentage of deforestation corresponds negatively with farm size (i.e., the larger the farm, the smaller the percentage deforested), absolute deforestation (i.e., total deforested area in hectares) is positively correlated to farm size. In absolute terms, the contribution by small farmers to regional deforestation pales in relation to the contribution by large farmers (Table 2). However, this relationship varies for different parts of the region.

4.2.1. Santarém example. The estimated deforestation rate and the factors explaining this rate are sensitive to the unit of measurement, particularly when they are assessed in relation to property size. Figure 3 illustrates these relationships for the Santarém region of Brazilian Amazonia. Whereas small farmers (e.g., farm properties that are 200 ha or less) tend to have higher proportions of areas in use, the absolute size of deforested area is small when compared to large farmers (e.g., farm properties larger than $200 \mathrm{ha}$ ), despite the fact that the deforested area represents a smaller percentage of a largeholder's property. Analyzing private properties of different sizes in the Santarém-Belterra region, we found that, in absolute terms, while small farmer deforestation events tend not to exceed 5 ha, largeholders deforested areas ranging from 10 to 500 ha. From 1986 to 1999 in the area examined, smallholders together deforested approximately 1641 ha of land, while largeholders together deforested 6064 ha. Similar patterns can also be found in terms of areas maintained in use and clearing of secondary succession. Smallholders maintained up to $82 \%$ of their property in use, while largeholders had less than $5 \%$ in use. In absolute terms, smallholders had between 0 and 50 ha of area in production, while largeholders had up to 100 ha of area, which was not a substantially different absolute amount of land in production relative to property size. However, this relationship is changing with the consolidation and expansion of soybean production and other large-scale mechanized crops [ $D^{\prime}$ Antona et al., 2006].

4.2.2. Uruará example. Table 3 illustrates deforestation by year and by aggregated property size classes. Because of the distribution of properties in this particular site, the research group made a distinction only between large glebas of 3000 ha $(n=9)$ and all other property sizes $(n=3263)$, the vast majority of which were 100 ha. The few intermediatesized farms (glebas), those with approximately 400 ha, are included here in the small farmer count, since there are cases where a family own multiple adjacent lots of 100 ha. They found that, in general, the amount of deforested land in the two size classes increased over time. The degree of increment, however, was different, with large glebas adding about $5 \mathrm{~km}^{2}$ of cleared land over the 13-year period, from 33.7 to $38.6 \mathrm{~km}^{2}$. Deforestation associated with these highly capitalized interests occurred early in the colonization period during the 1970s and has been rather static since that time. Smallholder deforestation has steadily increased, more than doubling from 447.1 to $1048.1 \mathrm{~km}^{2}$ of cleared area over the same period. This difference, however, represents the disproportional number of small farmers analyzed $(n=3263)$ vis-à-vis large land holdings $(n=9)$. Because the recent immigration and settlement of smallholders are not significant in the study area within the bounds of the cadastral map used for this analysis, large amounts of deforestation have not been caused by further settlement.

4.2.3. Ecuadorian example. In Ecuadorian Amazonia, patterns of land use were clearly visible according to the duration (e.g., years of settlement) and size of farm (Figure 4) [Barbieri et al., 2005]. The research group, which includes some of the authors here, found a decrease of forest through time across all farm sizes, though among the smaller farms ( $0-25 \mathrm{ha})$, the decrease of forest cover is highest in the early years of settlement and clearing. The latter mostly refers to the secondary wave of deforestation that occurred in the study region in the 1990 s linked to property subdivision. Meanwhile, the proportion of the cleared area in pasture increases with duration of settlement, while the cleared area in perennial and annual crops together increases only slightly over time, then decreases slightly, reflecting some replacement of crops by pasture over time on medium and larger farm sizes.

As mentioned before, the extensive subdivision of the original farms or fincas madres since 1990 has led to a second wave of deforestation [Bilsborrow et al., 2004; Barbieri et al., 2005; Pan and Bilsborrow, 2005]. Thus, the original farms containing no subdivision still had, in average, $56.1 \%$ of their total area covered by forests in 1999, while farms with two and three or more subdivisions had only $47 \%$ and $32 \%$ in forests, respectively [Pan and Bilsborrow, 2005]. Because of the processes of settlement that occurred in the Ecuadorian Amazon, virtually all of the patches of deforestation are small compared to those in the Brazilian Amazon, and with the subdivision process since 1990 , cleared patches are even smaller. Figure 5 shows how most deforestation in the NEA has occurred in very small patches of 1 to 5 ha.

\subsection{Summarizing Variables Explaining Deforestation Among Small Farmers}

The complexity of factors underlying land use decisions among small farmers defies any simplistic or linear expla- 


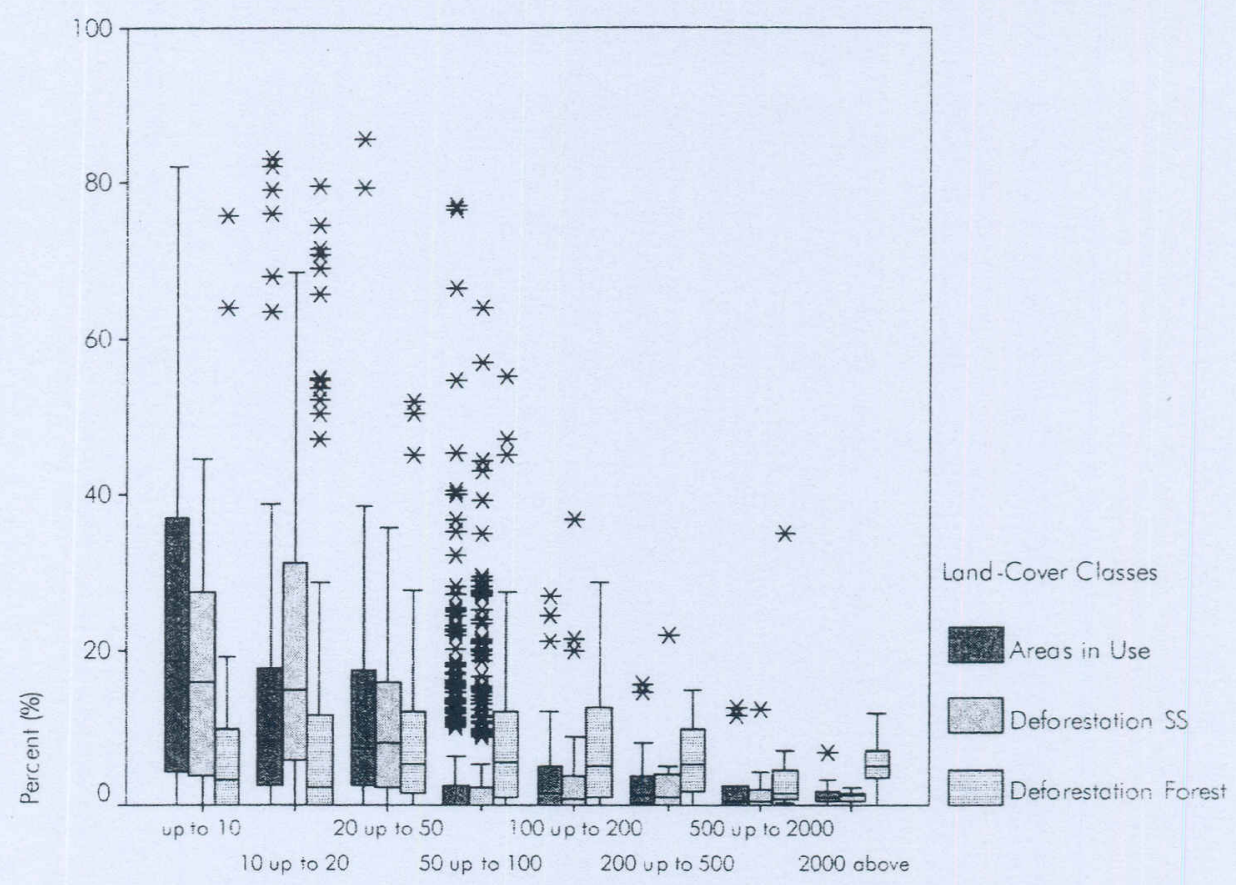

class of size property

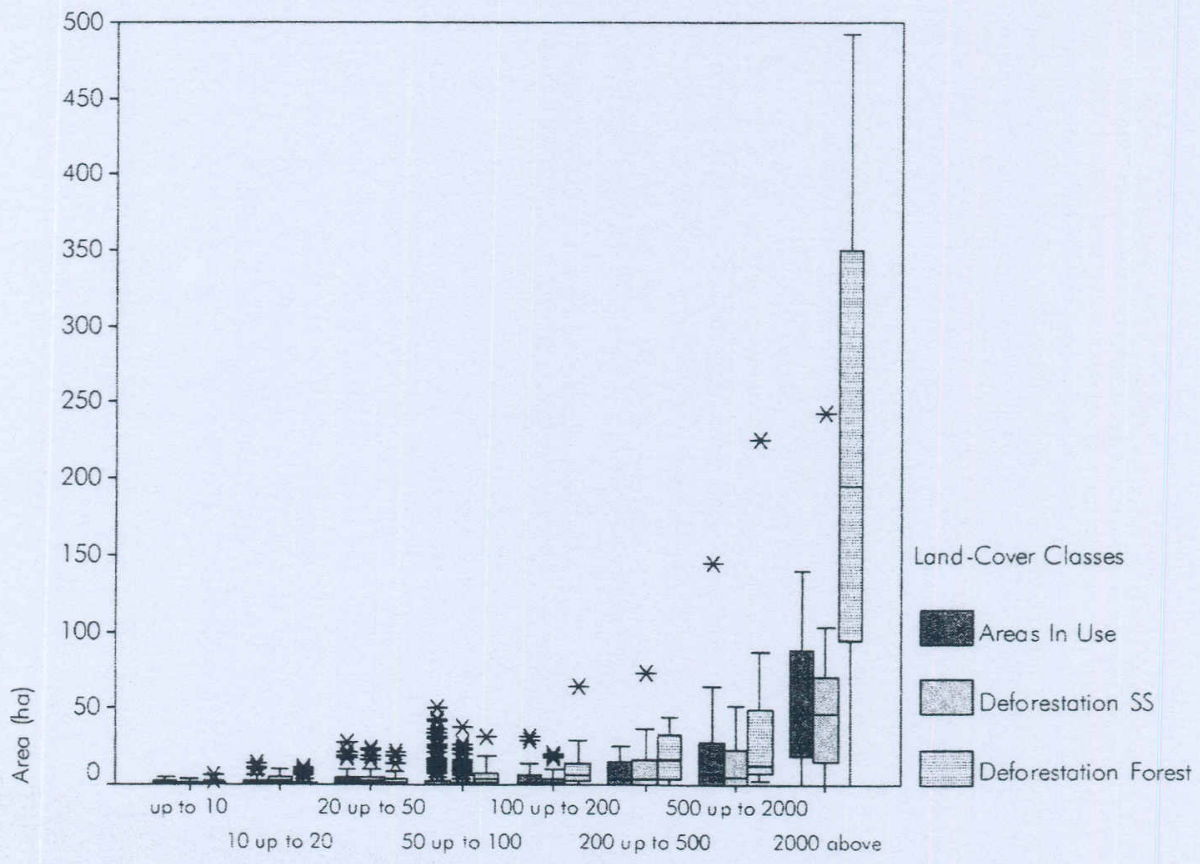

Figure 3. Land cover change (area and percentage of farm lots) according to farm-lot size classes for the BR-163-Santarém-Belterra Region (State of Pará) between 1986 and 1999. Land cover includes area maintained in use, areas deforested from secondary succession vegetation (SS), and areas deforested from mature forest. 
Table 3. Deforested Land and Annual Deforestation Rates in Uruará, Pará, From 1986 to 1998 by Size Class and Year

\begin{tabular}{cccccccc}
\hline Property Size & $\begin{array}{c}\text { 1986 Area } \\
\left(\mathrm{km}^{2}\right)\end{array}$ & $\begin{array}{c}\text { 1988 Area } \\
\left(\mathrm{km}^{2}\right)\end{array}$ & $\begin{array}{c}\text { Deforestation } \\
\operatorname{Rate}^{\mathrm{a}}\left(\% \mathrm{a}^{-1}\right)\end{array}$ & $\begin{array}{c}1991 \text { Area } \\
\left(\mathrm{km}^{2}\right)\end{array}$ & $\begin{array}{c}\text { Deforestation } \\
\text { Rate }^{\mathrm{a}}\left(\% \mathrm{a}^{-1}\right)\end{array}$ & $\begin{array}{c}\text { 1999 Area } \\
\left(\mathrm{km}^{2}\right)\end{array}$ & $\begin{array}{c}\text { Deforestation } \\
\text { Rate }^{\mathrm{a}}\left(\% \mathrm{a}^{-1}\right)\end{array}$ \\
\hline $\begin{array}{c}\text { Large farms (Glebas }) \\
(n=9) \geq 3,000 \text { ha }\end{array}$ & 33.7 & 29.9 & -3.2 & 36.4 & 7.2 & 38.6 & 0.7 \\
All other $(n=3.263)$ & 447.1 & 578.5 & 3.3 & 750.6 & 9.9 & 1.048 .1 & 4.9 \\
\hline
\end{tabular}

${ }^{2}$ Percentage rates are annualized for the periods 1986-1988, 1988-1991, and 1991-1999. Source is Aldrich et al. [2006].

nation of deforestation, which, nevertheless is unfortunately common with this topic. Although we highlight the importance of specific variables, one should remember that small farmers make land use decisions in a multidimensional way. In other words, a decision to deforest may represent at the same time a reaction to a market opportunity (e.g., price of beef or a crop), a way of increasing land value and property legitimacy (e.g., deforestation as a proof of "use"), and/or a step toward forming a farm. The rate, timing, and form of deforestation, thus, will be influenced by different conditions and needs of farm families, such as their economic and social expectations, household size and composition, knowledge of forest resources, previous experiences and preferences, technology and capital available, and location of the farm in terms of distance and accessibility. Differ- ent processes, demographic, socioeconomic, cultural, and environmental, are at work and interact at different spatial and temporal scales to promote different land use strategies [Kaimowitz and Angelsen, 1998; Wood and Porro, 2002; Perz, 2001; Brondizio, 2006].

The determinants of deforestation include both household factors and exogenous factors, many of which are regionand country-specific, including the pressure of commodity markets and national policies, such as incentives for agropastoral expansion aiming at export, oil related investment, and conservation efforts. Table 4 illustrates the importance of different variables explaining deforestation among small farmers, particularly those in colonization areas, and the studies examining the importance of these variables. In sum, simplistic analysis of causality provides an ill picture of these
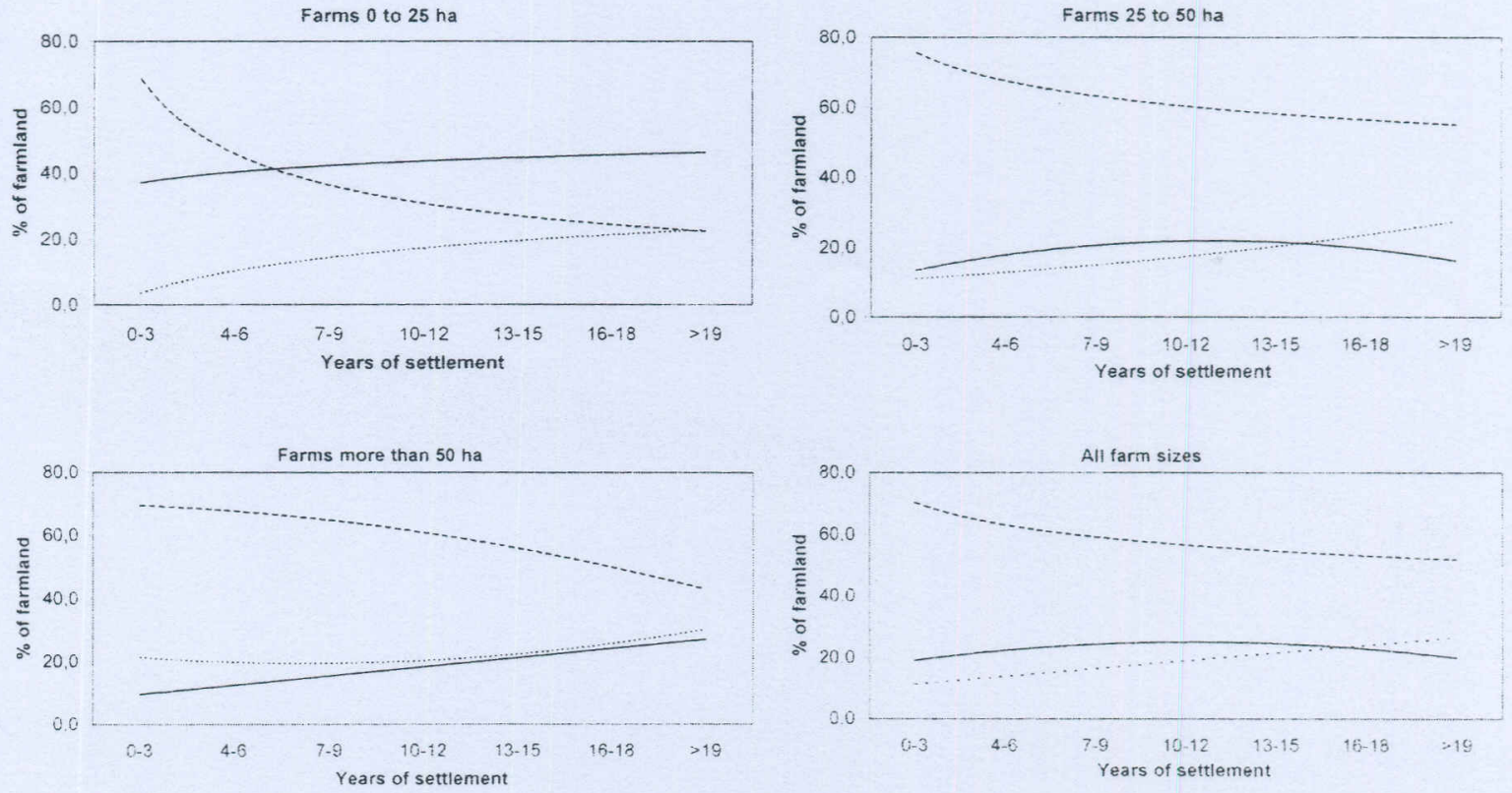

Figure 4. Patterns of land use according to duration (years of settlement) by size of farm in the Ecuadorian Amazon. Reprinted from Barhieri et al. [2005], with kind permission from Springer Science and Business Media. 

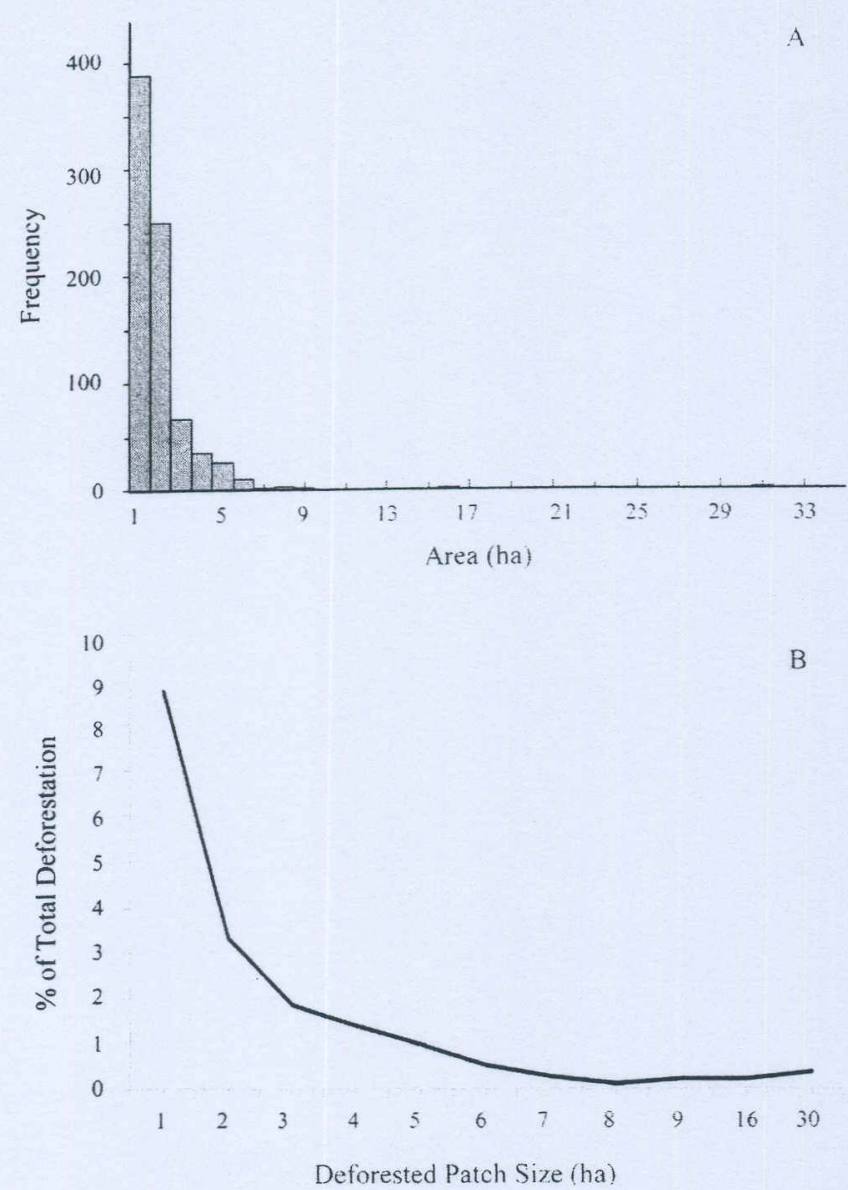

Figure 5. Forest patch size frequency (a) and percent of total deforestation (\%) (b) within sampled farms.

relationships. Thus, we do not want to convene the idea that a single variable can explain deforestation, but illustrate the relative role of specific factors influencing the process.

For example, according to different studies, besides age of the farm and time of settlement, distance to market represents one of the most important variables explaining deforestation among small farmers, particularly those settled in colonization areas. Several studies have shown that distance to markets have a negative impact on deforestation [Pichón, 1997; Walker et al., 2002; Caldas et al., 2007]. In many studies, market factors are used as a proxy for distance to market in explaining deforestation; however, these studies, in attempting to model individual agents, may fail to capture the use of natural resources on the landscape and the role of local markets (e.g., cattle commercialization between neighbors). Land market is also a key factor explaining deforestation, in some cases, independent of distance and location. Since cleared land has higher market value (for legal and economic reasons), farmers, large and small, may choose to invest in land clearing and deforestation to increase the value of their property or to speculate in areas expected to be targeted for agropastoral expansion. In the process, they may adopt a combination of annual crops followed by pasture. which can help to maximize short-term return and minimize risks (i.e., receive return from crops, open new opportunities with pasture, and increase the market value of the farm) [Vosti et al., 2003]. For instance, for more than two decades, cattle ranching has been widely adopted by smali farmers in Brazil as a strategy to secure fast returns, to facilitate cooperation with neighbors on raising and expanding herds, to minimize risks associated with storage and dependency on transportation (of perishable crops), and to improve their ability to negotiate and sell their livestock to a wide and diverse group of buyers [Hecht, 1993].

Other attributes are also important, such as level of wealth [Pichón, 1997; Alston et al., 2000; Walker et al., 2002; Alston et al., 1993] and length of residence on the property [Pichón, 1997; Walker et al., 2002; Vanwey et al., 2007]. For example, the time of settlement in the NEA, as in Brazilian Amazonia, is an important factor in land clearing, with less clearing on more recently settled land [Pan et al., 2004, 2007]. Both Pan et al. [2007] and Barbieri et al. [2005] note that the relationship between time since settlement and deforestation is not a strictly causal relationship, since it also indicates the location in time and space of different cohorts of migrant colonists. Thus, more recent cohorts have to settle farther from roads and towns. In the NEA, for instance, older farms, closer to roads and towns, experienced the most population growth in 1990-1999 (Figure 6), but less deforestation than the more recent cohorts, reflecting the faster pace of deforestation on farms settled more recently, since they are in the early stages of settlement.

Incorporating demographic variables to explain the deforestation in the region, we note that family size [Pichón, 1997; Pichon et al., 2002], number of men in the household [Walker et al., 2002; Pan and Bilsborrow, 2005; Caldas et al., 2007; Sydenstricker Neto and Vosti, 1993], and level of dependency [Walker et al., 2002] have an impact on either agricultural systems or in the amount of land to be deforested. Marquette [1998] and Barbieri et al. [2005] also note the important effects of the family life cycle and household type in land use change, particularly according to the Chayovian consumer/labor ratio, which was found to be important in the colonization area [Marquette, 1998], including in the buffer area of the Cuyabeno Wildlife Reserve [Mena et al., 2006a].

Pan and Bilsborrow [2005] studied the determinants of land use in 1999 (shares of each farm in four different forms of land use, in forests, in perennial crops such as coffee, in 


\section{SMALL FARMERS AND DEFORESTATION IN AMAZONIA}

Table 4. Summary of Variables Influencing Deforestation Among Small Farmers

\begin{tabular}{|c|c|c|}
\hline Independent Variable & Type of Correlation $^{a}$ & Examples From the Literature \\
\hline $\begin{array}{l}\text { Age, length of residency, } \\
\text { and family life cycle }\end{array}$ & + & $\begin{array}{l}\text { McCracken et al. [1999], Moran et al. [2002], Brondizio et al. } \\
\text { [2002], Walker et al. [2000], Pichón [1997], Caldas et al. [2007], } \\
\text { Vanwey et al. [2007], Perz [2001], Perz and Walker [2002] }\end{array}$ \\
\hline $\begin{array}{l}\text { Access to credit and number } \\
\text { of credit acts }\end{array}$ & + & $\begin{array}{l}\text { Walker et al. [2000], Pichón et al. [2002], Ludewigs et al. [2009], } \\
\text { Tura and Costa [2000] }\end{array}$ \\
\hline $\begin{array}{l}\text { Household labor and number } \\
\text { of men }\end{array}$ & + & $\begin{array}{l}\text { McCracken et al. [2002], Futemma and Brondizio [2003], } \\
\text { Pichón [1997], Sydenstricker Neto and Vosti [1993], Walker et al. [2002], } \\
\text { Pan and Bilsborrow [2005], Caldas et al. [2007] }\end{array}$ \\
\hline Hired labor & + & Pichón et al. [2002], Walker et al. [2000, 2002] \\
\hline Mechanization and chainsaw & + & Pichón et al. [2002], Pichón [1997] \\
\hline Lot size & $\begin{array}{l}\text { Relative deforestation - } \\
\text { Absolute deforestation + }\end{array}$ & Walker et al. [2000], D'Antona et al. [2006] \\
\hline Pasture (\%) & +4 & $\begin{array}{l}\text { Moran et al. [2002], McCracken et al. [1999], Walker et al. [2000], } \\
\text { Pichón [1997], Ludewigs [2006], Murphy [2001] }\end{array}$ \\
\hline Deforested $(\%)$ & + & McCracken et al. [1999], Vanwey et al. [2007] \\
\hline $\begin{array}{l}\text { Lot turn over } \\
\text { (number of owners) } \\
\text { and lot aggregation }\end{array}$ & + & $\begin{array}{l}\text { Ludewigs [2006], Ludewigs et al. [2009], Vanwey et al. [2007], } \\
\text { D'Antona et al. [2006] }\end{array}$ \\
\hline Distance to markets & - & $\begin{array}{l}\text { Pichón [1997], Moran et al. [2002], McCracken et al. [1999], Caldas } \\
\text { et al. [2007], Walker et al. [2002] }\end{array}$ \\
\hline Topography (flatness) & + & McCracken et al. [1999], Pichón [1997], Pan et al. [2004] \\
\hline $\begin{array}{l}\text { Soil quality and water } \\
\text { availability }\end{array}$ & + & Caldas et al. [2007], Moran et al. [2002], Pichón [1997] \\
\hline Level of wealth and income & + & $\begin{array}{l}\text { Alston et al. [1993], Jones et al. [1995], Pichón [1997], } \\
\text { Murphy [2001] }\end{array}$ \\
\hline Land security & \pm & $\begin{array}{l}\text { Futemma and Brondizio [2003], Alston et al. [2000], Pichón [1997], } \\
\text { Toniolo [2004] }\end{array}$ \\
\hline
\end{tabular}

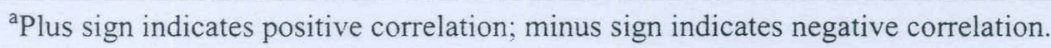

annual crops, and in pasture) at the household level, based upon a multiresponse linear model. Their results reveal the most powerful determinants to be plot size, plot access to road and the nearest community, years living on plot, household labor availability, especially males, and population density on the plot. It is striking that population density is a powerful factor even when plot size and all demographic variables are included, which provides strong support for the important, independent effects of population pressure.

Yet, data from the Amazon estuary shows that afforestation can occur simultaneously with population increase in urban and rural areas. The estuarine region (over 20 municipalities in Brazil) has witnessed a forest transition and rates of deforestation close to zero, due to the expansion of agroforestry-based açaí fruit production and a forest economy, which involves a variety of timber and nontimber resources. In addition to expanding national and global markets for these products, estuarine farmers are culturally familiar and knowledgeable about forest management and resources, which has allowed them to respond to market opportunities using local management technologies and multicropping agroforestry systems [Brondizio, 2008; Jarvis et al., 2007;
Rerkasem and Pinedo-Vasquez, 2007; Pinedo-Vasquez and Padoch, 2009; Brookfield, 2001; Padoch and PinedoVasquez, 2006]. Ironically, these same systems are often regarded as backward and unproductive.

Some studies have observed that large deforested areas often appear on properties that have families with substantial family labor resources, including hired labor [Pichón, 1997; Walker et al., 2002; Pan and Bilsborrow, 2005]. In Ecuador, as in Brazil, deforestation within colonization areas also relates to the duration of residence on the property, education level, and age of household head [Pichón, 1997; Alston et al., presented paper, 1993]. Families with longer periods of residency have deforested larger areas; however, the type of forest used also varies with duration of residence, in that, families with longer settlement histories tend to eventually use and clear secondary forests, compared to more recent settlers who clear remaining primary forest areas [Brondizio et al., 2002; Perz and Walker, 2002]

Environmental and resource constraints also structure the amount and type of deforestation, particularly in combination with each other. For example, Pan et al., [2004] show that landscape complexity and fragmentation, two important 


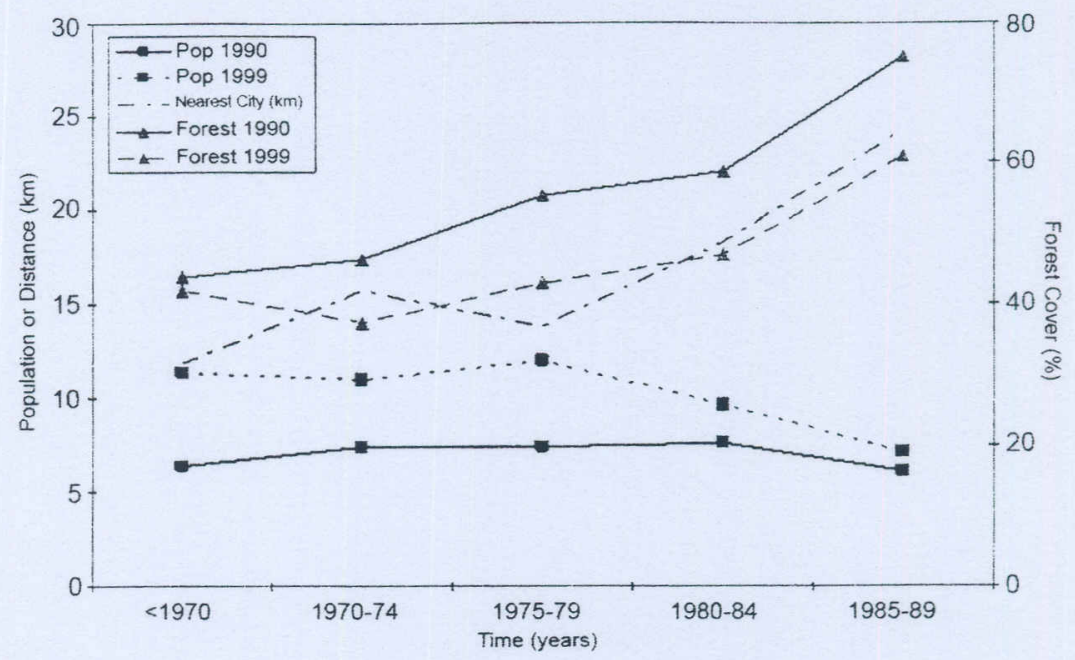

Figure 6. Pop 1990, finca population in 1990; Pop 1999, Finca population in 1999; Forest 1990, the percent of forest cover on a finca in 1990; Forest 1999, the percent of forest cover on a finca in 1999; Nearest City (km), Euclidean distance from the finca to the nearest of the four major communities in 1999. Reprinted from Pan et al. [2007], with kind permission from Springer Science and Business Media.

measures within Landscape Ecology that have implications for the flux of matter and energy in ecosystems, are associated with household size and composition, expansion of the road and electrical networks (increasing access of farm households), year of plot settlement, and topography. This indicates that in the Northern Ecuadorian Amazon, the spatial arrangement of agricultural plots and forested patches within the landscape have strong connections with changing socioeconomic processes. Soil quality also directly affects land allocation [Moran et al., 2002] and, in combination with other factors such as topography and water, can influence type of crop adoption and deforestation in different ways [McCracken et al., 1999]. Pan et al. [2004], for instance, state that flat land is important to annual crops and pastures and may be preferred for clearing. Caldas et al. [2007] show that soils suitable for pasture and with water can positively affect the total area deforested. However, their results are not sustained when spatial autocorrelation analyses are implemented. In short, several factors related to the rapid population growth, plot subdivision, plot location/accessibility, and resource availability all have contributed to the conversion of forest to crops and pasture for cattle, which in turn has created a more complex and fragmented landscape.

Even though demographic and environmental factors are implicated as drivers of deforestation, credit and land security, are also important. That is, forest conservation is positively associated with land security [Pichón, 1997; Alston et al., 2000; Fearnside, 2001]. Nevertheless, there are disagreements regarding this view. Walker et al. [2000] argue that land security can be a facilitator in credit acquisition, and consequently, can be used for pasture formation.

Finally, it is increasingly recognized, but little studied, that rapid urbanization associated with adjacent processes of lot turnover and land speculation in agrarian settlements shape the spatial pattern and rate of deforestation for years to come. For example, the main urban centers in the NEA have had high rates of population growth and constitute key centerpoints or poles of development. Several studies have found proximity to these towns and their markets' important factors contributing to deforestation aiming at increasing land value [Mena, 2001; Bilsborrow et al., 2004; Pan et al., 2004; Barbieri and Carr, 2005; Pan and Bilsborrow, 2005]. However, as the estuary example above illustrates, this relationship depends on the perceived value (e.g., water protection, recreation, symbolic meaning, storage of resources) and market for forest resources. In some cases, market forces can promote a relationship between farmers and forests inverse to that described by the Ecuadorian case above or other colonization areas in Brazil [Brondizio, 2008, 2009]. It is also important to note that colonist farmers understand better the importance of forests over time. Most farmers tend to set aside forest areas dedicated to protecting water sources and hunting grounds and to have access to various raw materials needed for daily farm operations, such as wood, fibers, and roof covers [Muchagata, 1997; Brondizio et al., 2002; Campos, 2006]. Furthermore, recent studies have called attention to the growing interdependency between rural and urban populations that rely on forest resources for their production

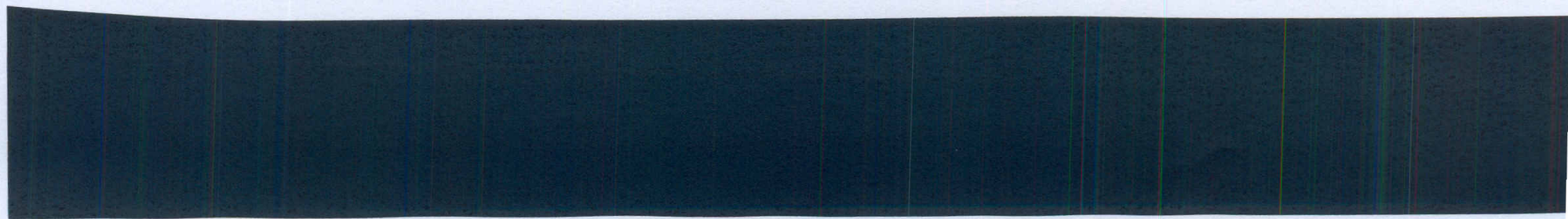


and consumption needs, but also rely on city services for health, education, and commerce. This pattern of rural-urban connections and interdependency represents a growing reality for the Amazon, within which small farmers play a vital role [Padoch et al., 2008].

\section{SMALL FARMERS, LAND USE, AND DEFORESTATION: MOVING BEYOND MISCONCEPTIONS}

As we stated in the beginning of this chapter, small farmers form diverse social groups in Amazonia, but share many widespread misconceptions about themselves and the region, as described by Schmink and Wood [1992, p. 6]: (1) small producers are not efficient; (2) peasant people are culturally retrograde; (3) extractive activities are backward; (4) traditional knowledge is worthless; (5) tropical forests provide few useful economic goods, with only a limited number of hardwoods; and (6) community property rights are antithetical to private property. Such development paradigms create inherent barriers to protecting the environment, to preserving the boundaries of Indian lands, and to defending the rights of small farmers [Schmink and Wood, 1992:6]. In this context, an interpretation of small farmers and deforestation in Amazonia should be concerned with the politics of regional development, interest groups and the distribution of economic incentives, the role of external forces, and, not least, the views of development and what constitutes "modernization" put forward by different sectors of society. Below, we discuss three common misconceptions associated with small farming land use systems and deforestation in Amazonia.

\subsection{Misconception 1: Small Farmers Have Backward Land Use Systems Associated With Low Productivity and Extensive Deforestation and Subsistence Production}

Small farm land use varies from intensive to extensive methods, including sophisticated agricultural systems combining indigenous technology, as well as high input production systems [Brondizio, 2004; Costa et al., 2006]. In colonization areas, land use evolves with the age and experiences of farmers in the region. Small farming land uses include various forms of swidden cultivation, horticulture and polyculture, intensive agroforestry, forest management and extractivism, and cattle ranching. Access to technology is a recurrent problem among small farmers who often have to rely on the use of fire and manual tools that limit their ability to change their land use strategies, even amid perceived problems such as extended drought [Brondizio, 2004; Brondizio and Moran, 2008; Costa, 2006]. Data from INCRA and IBGE [Guanziroli et al., 2001] show that small farmers, especially in the Brazilian Amazon have minimum access to extension service and technology: $5.7 \%$ of farmers use extension services, $9.3 \%$ of farmers have electric energy, $3.7 \%$ of farmers use mechanized implements and other forms of technologies (such as animal traction), and $87.1 \%$ of farmers depend on manual labor for land use activities. These regional numbers corroborate household surveys carried out in the sites illustrated here. Furthermore, the "dismantling" of the Empresa de Assistência Técnica e Extensão Rural (EMATER) extension service in Brazil after 1990 has contributed to the lack of assistance and support to small farmers. Although its support varies across states, and in spite of the effort of many agricultural extension agents, in most of Amazonia, they do not have conditions even to visit local farmers, or as one extension agent in Pará reported, 'EMATER now-a-days is a 'dead-alive' (vivo morto), that is here, but without a working phone line, gasoline and transportation, and technicians to attend to farmers requests" [Brondizio, 2004, field notes]. Yet, it is usually among small farmers that we find the most creative land use solutions, such as planting consortiums, better land preparation methods, land use diversification, and a high degree of agrobiodiversity. Colonist farmers tend to experiment with different methods of land use management, usually combining techniques brought from other regions.

Despite having smaller property sizes, limited access to technology, and technical assistance, small farmers (smallholders) compare positively to largeholders in Brazil. According to some studies, in Amazonia, small farmers have an average annual income of RS52/ha (approximately US\$29), almost five times more than the largeholders, while in southern Brazil, smallholders have an average annual income of R\$241/ha (approximately US\$128) and largehoiders an average annual income of R\$99/ha (approximately US\$53) [Guanziroli et al., 2001]. Different examples of small-scale, highly productive systems exist in the region, such as among agroforestry farmers of Tomé-Açu, cocoa farmers of the Transamazon, açai farmers throughout the Amazon estuary, horticultural farmers around large urban centers, and manioc farmers in many areas who use multicropping and multivariety systems.

Small farmers throughout the region are highly engaged in market dynamics, responding to price changes and new market opportunities, while combining household consumption and commercialization. Though many crops are produced for familial consumption, such as manioc, beans, rice, corn, and açai fruit, depending on the region, these crops also have been produced exclusively for commercialization. Important commodity products for small farmers have included not only manioc, rice, beans, and corn. but also black pepper, coffee, cocoa, a great diversity of fruits and seeds. 
horticultural products, timber and nontimber forest products, husbandry, and fish farming. Yet, in Brazil, and according to some studies, although small farmers have $25 \%$ of the overall agricultural credit, family properties are responsible for approximately $37.9 \%$ of total national production, at least part of which is for export. For example, almost $20 \%$ of smallholders in Brazil sell more than $90 \%$ of their total production, while close to another $40 \%$ sell more than $50 \%$ of their production. At the national level, smallholders are responsible for the production of $52 \%$ of milk from cattle, $58 \%$ of pork, $40 \%$ of chicken and eggs, and the majority of fresh produce used for daily consumption [Guanziroli et al., 2001]. However, small farmers and small farming groups face significant constraints in transportation and the ability to negotiate prices, despite their engagement in global market systems and organization in various forms of cooperatives and associations. They tend to pay higher transportation prices to supply food to local urban markets and, in most cases, have to carry their products on their own backs or in buses, on truck rides, on mules, and on bicycles. Many, if not most, depend on negotiations with middleman to sell their products, which make their economic return per unit produced lower, independent of their success and productivity as farmers [Brondizio et al., 2003]. Successful local programs to facilitate producers to sell directly in urban areas, such as the case of Altamira and Santarém, are limited and lack wider support. Furthermore, the lack of transformation industries to process agricultural goods and natural resources within the region condemns farmers to sell their products as unprocessed or semiprocessed raw material, which perpetuates value added concentrated outside the region.

\subsection{Misconception 2: Small Farmers Contribute to Amazonian Deforestation as Much as Large Farmers}

While the contribution of small farmers to Amazonian deforestation varies across countries, states, subregions, and periods, in aggregated terms, small farmers contribute to a small proportion of regional deforestation area, when compared to their large-scale counterparts (Table 2). During the 1990s, INPE's deforestation assessments, including frequency of clearing by size class, were often used in the media to finger-point the causes of deforestation toward small farmers. Even today, this has continued to be the case, although small farmers are currently being treated as part of an aggregate category under INCRA [among numerous examples see OESP. 2008a, 2008b; Folha Online, 2008]. Several authors point out smallholders as the main deforesters, while not considering their relative contribution visà-vis other sectors and the units of analysis used to make comparisons. A common problem is the general association of small farmers with shifting agriculture, which, in turn. is considered by nature as destructive and unproductive. It is common place to find interpretations of small-scale production systems using shifting cultivation as the main contributors to global deforestation and the main threaten to biodiversity [Primack and Corlett, 2005; Palm et al., 2005; Hartshorn, 2006]. While the contribution of shifting cultivation to deforestation varies enormously across the world. Amazonian small farmers are commonly lumped together as part of this global category [Netting, 1993]. This kind of analysis, while raising some important issues and relevant to particular parts of the world, rely mostly on a general stereotype applied to shifting cultivation systems [Dove, 1983] rather than examining how they vary in time and space, in some cases, actually contributing to increased habitats and biodiversity [Pinedo-Vasquez et al., 2002]. Another common example of this type of discourse has been illustrated by statements from researchers and technicians from federal research agencies who argue that the lack of technology makes small farmers the main agent of deforestation, due to low productivity. For instance, "smallholders deforest to eat, that is, to grow corn, rice and beans, and afterwards turn the land into pasture," while they view that "it is wrong" to say that largeholders are responsible for deforestation because they have technology that allows them to have higher production in a smaller area. They point out that low technology means low level of occupation, in terms of number of cows per hectare ( $1.2 \mathrm{head} / \mathrm{ha}$ with low production, and up to 2 heads/ha with higher technology input), but fail to consider the variability of level of productivity, the diversity of land use systems employed by small farmers, the level of support they receive, the history of conflicts associated with these regions, and the role of speculative deforestation among large farmers and loggers [Costa, 2004].

Some studies have addressed the relative role of farm size and economic scale upon regional deforestation and demonstrated a lesser role of smallholders in driving deforestation in Amazonia relative to large holders, contrary to common generalizations about small farmers. For example, in a study of the Brazilian portion of the Amazon basin, Fearnside [1993] estimated that large-scale holders were responsible for $70 \%$ of all deforestation in 1990 and 1991, while Walker et al. [2000] showed that the relative degree of accountability is spatially variable. In a microregion in the south of Pará, where the influence of the Agency for the Development of the Amazon (SUDAM) was strong in the 1970s and 1980s, large enterprises accounted for close to all of the land cleared (in 1986). while along the Transamazon Highway, in the vicinity of the Uruará area, the proportion was only $8 \%$ (in 1992). Location and spatial organization of settlement areas also are significant in explaining patterns of deforestation.

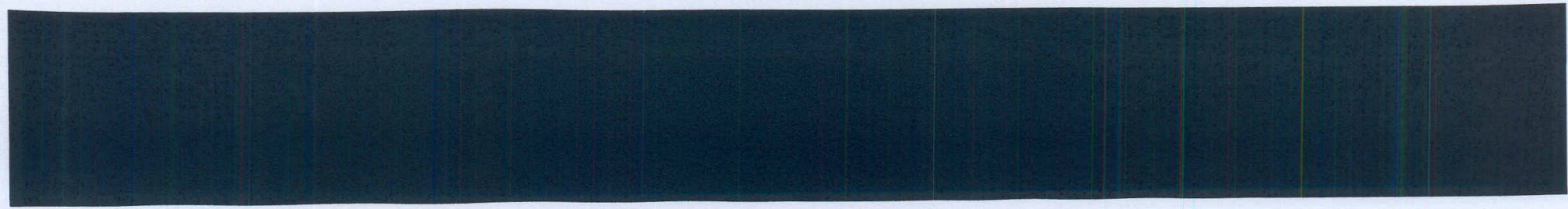


Analysis of deforestation in relation to farm size thus needs to account for both absolute (e.g., ha) and relative (e.g., \%) measures of deforestation. In general, we see an inverse relationship between these two measures, in relation to farm size, though these relationships also vary with location and context, history of occupation, and social group.

A great technological and economic divide exists between groups of small and large farmers in Amazonia. Field data collected among rural families in the Santarem region in 2001 and 2002 indicate that more than $90 \%$ of the farmers depend on axes, shovels, and machetes for their production, whereas large-scale producers use machines, chemical fertilizers, and pesticides, mostly subsidized by bank loans. The percentage of small farmers who were able to obtain (applied for and received) credit from 1998 to 2002 was lower than $5 \%$, compared to $80 \%$ among large farmers in this study area. The INCRA data confirm that limited access to technology, technical assistance, and financial support is widely found among small farmers all over Brazil, especially in the north and northern regions [Guanziroli et al., 2001]. On the other hand, riverine farmers of the Amazon estuary have been able to use their knowledge of multicropping systems to reach levels of intensification higher than any other regional production system and have transformed açai fruit agroforestry systems into the most important land use and economy activity in the region without any help from research and government agencies [Brondizio and Siqueira, 41997; Brondizio, 2008].

Despite their economic and technological disadvantages, which limit their ability to intensify production on the land, small farmers have been able to keep some portion of mature forest within their properties (rather than extensively clearing properties to increase production area). The research team reporting on the Santarém region found that on small private properties ranging in size from 0.9 to 200 ha, forest cover is approximately 41.89 ha and, on average, small farmers maintain approximately $60 \%$ of their properties in forest. However, by aggregating small farmers, we found that $85.5 \%$ of their land is kept in forest, as opposed to large farmers that maintain only $70.7 \%$ in forest (Table 5 ). The latter is a result of higher deforestation rates among large farmers, making their relative contribution to total deforestation significantly higher in this region.

\subsection{Misconception 3: Small Farmers, Particularly Colonist Farmers, Follow an Inexorable Path of Deforestation Unless Curbed by Government Actions}

The extent, amount, and trajectory of deforestation vary significantly at the farm lot level, depending on characteristics such as time in the region, knowledge of forest resources and views of forest as productive land, stage of farm formation, household demographics, capital, short- and longterm goals, and market opportunities for different crops (see Table 4 for a detailed list of variables). The high rate of adoption of cattle ranching among small farmers correlates to risk minimization strategies, aggregation of land value, and economic incentives to adopt pasture and cattle ranching as land use strategies. At the same time, small farmers adopt diverse land use strategies, including annual and perennial crops, different forms of husbandry, fishing and hunting, and a variety of off-farm and sharecropping labor arrangements.

Secondary forest areas are widely used in farming systems among small farmers. Data from the Transamazon region of Altamira-Medicilândia and BR-163 region of SantarémBelterra indicate that among colonists, phases of lot formation lead to increased use of fallow land, and older, settled farmers tend to use more secondary forests than mature forests [Brondizio et al., 2002]. These results also show that between 1986 and 1999, older, settled farmers cleared more secondary forests than mature forests, compared to recent-settled smallholders and largeholders (Figure 3). Even small farmers with less than 10 ha were still able to maintain

Table 5. Absolute and Relative Distribution of Land Cover Changes in the Santarém-Belterra Region. Pará, From 1986 to 1999 According to Different Property Sizes: Small and Large

\begin{tabular}{|c|c|c|c|c|c|c|c|}
\hline $\begin{array}{l}\text { Property } \\
\text { Size }\end{array}$ & $N$ & $\begin{array}{l}\text { Areas } \\
\text { in Use }\end{array}$ & $\begin{array}{c}\text { Clearance of } \\
\text { Secondary } \\
\text { Forest }\end{array}$ & $\begin{array}{c}\text { Deforestation of } \\
\text { Mature Forest }\end{array}$ & Regeneration & Mature Forest & Total \\
\hline \multicolumn{8}{|c|}{ Absolute Area, ha ${ }^{\mathrm{a}}$} \\
\hline$<200$ ha & $1,823.00$ & 683.64 & 610.11 & 1.641 .33 & 907.38 & $22,823.73$ & $26,700.03$ \\
\hline$>200$ ha & 37.00 & $4,829.31$ & $4,745.25$ & $6,063.93$ & $6,363.18$ & $53,800.65$ & 76.068 .36 \\
\hline \multicolumn{8}{|c|}{ Relative Distribution Area, \% } \\
\hline$<200$ ha & $1,823.00$ & 2.60 & 2.30 & 6.10 & 3.40 & 85.50 & 100.00 \\
\hline$>200$ ha & 37.00 & 6.30 & 6.20 & 8.00 & 8.40 & 70.70 & 100.00 \\
\hline
\end{tabular}

${ }^{a}$ Aggregated for all properties within each class. 
areas of forest, albeit smaller than areas of secondary vegetation. The majority of small farmers with lot sizes up to 10 ha maintain at least $25 \%$ of the land in forest, while those with 10 to 20 ha maintain approximately $40 \%$ or more, and most farmers of 20 to 50 ha lots maintain more than $50 \%$ in forest. However, as noted above, one finds significant variation within settlements and between subregions of Brazilian Amazonia.

Time in the region also relates to a great appreciation and knowledge of the economic and ecosystem services of forest areas and to forest conservation. However, market opportunities can be strong enough to motivate deforestation or reforestation independent of time in the lot and available technology. During the 1990 s, for instance, farmers along the Transamazon increased deforestation to form pastureland during a period of high prices for beef and declining prices for cocoa. On the other hand, farmers in the Amazon estuary have virtually abandoned deforestation and annual crops during the past two decades in favor of forest management and agroforestry systems for regional, national, and international markets. However, along the Transamazon, besides shifting prices for beef and cocoa, rates of pasture expansion have been influenced by an active land market formally or informally sanctioned by INCRA. In summary, small farmers tend to decide their deforestation strategies based on external and internal conditions during different phases of their farm operation and family life cycle, but particularly market opportunities for land and commodities.

\section{CONCLUSION}

It is important to understand small farmers in the context of the political ecology of deforestation and conservation in Amazonia, hence, breaking old assumptions that rural communities are homogeneous and adapted or are failed adaptations to external environments. This is an old but recurrent discussion in Latin America [Durham, 1988; Roseberry, 1993]. The development paradigm guiding public policy since the 1960 s has led policy makers to condemn small-scale production systems as transitory and inefficient without addressing the problems faced by rural populations. Most public policy programs have a tendency to frame small-scale production as only related to family consumption needs, while failing to consider their contribution and wider economic potential, thus missing the opportunity to support more inclusive forms of regional development. In spite of political discourse and numerous public policy programs, this is still the case in Amazonia.

Amazonia parallels other regions of Latin America where a development model intersects with rural impoverishment, environmental problems, and inequality in land distribution in addition to the lack of access to services such as education and health, and lack of support for local entrepreneurship. All these factors lead to a high rate of lot turn over and increase the impoverishment of small-scale farmers. One of our comparative studies involving three settlement in the states of Pará and Acre indicates a rate of lot turnover around $75 \%$ over the life of these settlements, which illustrates not only the active land market within agrarian settlements in Brazil, which returned to land concentration under the eyes of agencies such as INCRA, but also the scale of challenges, economic, cultural and social, infrastructural, faced by small farmers [Ludewigs et al., 2009]. Small farmers have been disregarded already very early in the developmental project of Amazonia [Moran, 1981; Wood and Schmink, 1979] and continue to be so today amid new settlement projects, even by policies targeted at small-scale production systems. Perhaps, the current precarious situation of EMATER offices throughout Amazonia illustrates also the situation of the population they aim at serving.

Even in areas of active economy involving small farmers, such as the açaí fruit economy of the Amazon estuary, rural households depend mostly on retirement income of family members and government aid such as the bolsa familia (family-aid) [Brondizio, 2009]. Lack of governance in the Amazon frontier has been cited as one of the main problems regarding deforestation [Nepstad et al., 2002]. The disregard of small farmers in relation to credit, extension services, technology, transportation, and access to markets tends to create and promote land speculation and a vicious cycle of selling small lots to largeholders and moving to new frontier forest land and urban areas. This is an active and ongoing situation throughout Amazonia. More integrated policies are needed, which incorporate effective agrarian programs (e.g., technology, extension services, credit, and support for commercialization), legal and institutional infrastructure (e.g., land titling, legal definition of rights of resource use, and monitoring and sanctions on forest clearing), and sociocultural recognition (e.g., valorization of forests as productive land; valorization of small-scale production systems). Similarly, conservation policies should include and promote diverse local systems of production without trying to "freeze" and "essentialize" smallholders as "traditional populations" expected to protect forests with disregard of their economic needs. Perhaps most important, small farmers, and the region as a whole, would benefit from policies aiming at promoting value aggregation of agricultural and forest resources, which could facilitate commercialization to the advantage of producers, generate employment in urban and rural areas, and generate revenue to be reinvested at the municipal scale. In other words, small farmers would benefit from policies fostering the development of transformative industries within

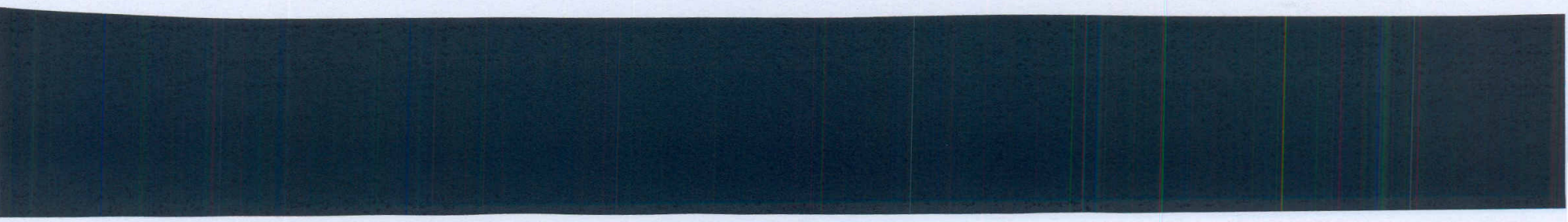


the region, which involves the participation of producers. External subsidies to promote conservation-development programs in the region have proved at best to be transitory in the past. Credits for carbon or subsidies for protection of environmental services will run into similar problems if empty of mechanisms for economic participation and valorization of regional resources.

Small farmers form a sizable population in Amazonia and represent an important form of employment for a large contingent of people that otherwise have little or no option in a region with limited transformative industries and little employment outside the informal economy. Their contribution to food production for regional consumption and export is undeniable and growing. Their presence in rural and urban areas through various forms of social and economic networks, and their presence in virtually all nonindigenous reserves of Brazilian Amazonia indicate their central role in the overall development and governance of the region. The quality and seriousness of public policies concerning the economic and social needs of small farmers will continue to influence their land use systems and role on regional land use and deforestation. More attention and fewer stereotypes will contribute to improve their condition and reconcile their economic contribution and environmental footprint in Amazonia.

Note added in proof. As this paper goes to press, IBGE [2009b] released a report (2 October 2009) confirming the overwhelming importance of small farmers for food production and security in Brazil (e.g., 70\% beans, $87 \%$ manioc, and $58 \%$ milk consumed nationally) and rural employment (employing $75 \%$ of the rural labor force). Confirming the analysis presented in this paper, the report shows small farmers producing more in less area. Collected for the first time as part of a national-level census (2006), these data confirm our arguments in favor of the social and economic importance of small-scale production systems at local and national levels and reaffirm our call to overcome misconceptions and the invisibility of small farmers in Brazil.

Acknowledgments. We thank the U.S. National Aeronautics and Space Administration (NASA) LBA-ECO Program (grants NCC5-334, NCC-695, NNG06GD86A), NSF HSD Program (grant BCS0527578), and NICHD (grant HD 358110-03/07) for supporting research at Indiana University's Anthropological Center for Training and Research on Global Environmental Change (ACT). We also thank NASA LBA-ECO for supporting the projects (NNG06GD96A) “'Spatially Explicit Land Cover Econometrics and Integration with Climate Prediction: Scenarios of Future Landscapes and Land-Climate Interactions" and the project (NCC5-694) "A Basin-Scale Econometric Model for Projecting Amazonian Landscapes," and the National Science Foundation for supporting the project "Patterns and Processes of Landscape Change in the Brazil- ian Amazon: A Longitudinal, Comparative Analysis of Smallholder Land Use Decision-Making-BCS137020 both at Michigan State University and which provided support to Marcellus M. Caldas. The Ecuador Project acknowledges the U.S. National Aeronautics and Space Administration (Grants NCC5-295 and Earth Science Fellowship NNG04GR12H), the National Institutes of Health (R01HD38777-01), and the Carolina Population Center, at the University of North Carolina at Chapel Hill, as well as the collaboration and support of the Ministries of Environment and Agriculture and the former National Planning Agency (CONADE). The GTZ Profors program and the Compton and Summit foundations also supported the 1999 survey fieldwork. We thank FAPESP for providing PostDoctoral Scholarship (n. 01/02578-2 and 03/01933-9) and FAPESP Research Financial Support (n. 01/11473-0) to Célia Futemma. We thank EMBRAPA-CPATU in Belém, EMBRAPA-NMA in Campinas, and EMBRAPA offices in Santarem, Altamira, and Belterra, the LBA Program, particularly the LBA office in Santarém, Pará State, Brazil, EMATER offices in different parts of the region, the IPAM office in Belém. We also thank colleagues at Indiana University's Department of Anthropology and ACT particularly Andrea D. Siqueira, Vonnie Peischl, Scott Hetrick, Linda Barchet, and all ACT graduate students and interviewers involved with these projects. A special thank you goes to all Amazonian farmers who kindly received us on many occasions. Finally, we are grateful for the insightful comments and suggestions of two external reviewers and the editors of this volume

\section{REFERENCES}

Adams, C., R. S. S. Murrieta, W. A. Neves, and M. Harris (Eds.) (2008), Amazonian Historical Peasants: Invisibility in a Changing Environment, Springer, Dordretch, The Netherlands.

Aldrich, S., R. T. Walker, E. Y. Arima, M. Caldas, J. Browder and S. G. Perz (2006), Land-cover and land-use change in the Brazilian Amazon: Smallholders, ranchers, and frontier stratification, Econ. Geogr., 82, 265-288.

Alston, L. J., G. D. Libecap, and B. Mueller (2000), Property rights to land and land reform: Legal inconsistencies and the sources of violent conflict in the Brazilian Amazon, J. Environ. Econ. Manage., 39, 162-188.

Araujo, R. (1993), La cité domestique: Stratégies familiales et imaginaire social sur un front de colonisation en Amazonie brésilienne, thèse de Doctorat, Nanterre-Paris X.

Barbieri, A. F., and D. L. Carr (2005), Gender-specific out-migration, deforestation and urbanization in the Ecuadorian Amazon, Global Planet. Change, 47, 99-110.

Barbieri, A. F., R. E. Bilsborrow, and W. K. Pan (2005), Farm household lifecycles and land use in the Ecuadorian Amazon, Popul. Environ., 27, 1-27.

Barreto, P., C. Souza Jr., A. Anderson, R. Salomão, and J. Wiles (2005), Pressão Humana no Bioma Amazônia, in O Estado da Amazónia, No. 3, 6 pp, Imazon, Belém. (Available at http:// www.imazon.org.br) 
Barreto-Filho, H. (2006), Populações tradicionais: introdução à crítica da ecologia politica de uma nação. in Sociedudes Caboclas Amazônicas: Modernidade e Invisibilidade, edited by C. Adams, R. S. S. Murrieta, and W. A. Neves, pp. 125-144, AnaBlume, São Paulo.

Barsky, O. (1984), La Reforma Agraria Ecuatoriana, Corporación Editora Nacional, Quito, Ecuador.

BASA (Bank of Amazonia) (2002), O Fundo Constitucional de Financiamento do Norte e o Desenvolvimento da Amazônia, M \& S Editora, Belém, Pará, Brazil.

BASA (Bank of Amazonia) (2004), Relatório das Atividades Desenvolvidas e dos Resultados Obtidos no Exercicio 2003 with Fundo Nacional de Financiamento do Norte, Gerência de Estudos Econômicos e Relações Institucionais, and Coordenadoria de Planejamento, Belém, Pará, Brazil.

Batistella, M. (2001), Landscape Change and Land-Use/LandCover Dynamics in Rondonia, Brazilian Amazon, CIPEC Dissertation Series, No. 7, Center for the Study of Institutions, Population, and Environmental Change, Indiana University. Bloomington, IN

Batistella, M., and E. F. Moran (2005), Human dimensions of land use and land cover in the Amazon: A contribution for LBA, Acta Amazônica, 35(2), 249-257.

Batistella, M., S. Robeson and E. F. Moran (2003), Settlement design, forest fragmentation, and landscape change in Rondonia, Amazônia, Photogramm. Eng. Remote Sens., 69(7), 850-812.

Batistella, M., E. F. Moran, and D. S. Alves (Orgs.) (2008), Amazônia: Natureza e Sociedade em Transformação, 1st ed., Editora da Universidade de São Paulo, São Paulo.

Bilsborrow, R. E., A. F. Barbieri, and W. K. Pan (2004), Changes in population and land use over time in the Ecuadorian Amazon. Acta Amazônica, 34, 635-647.

Brondizio, E. S. (2004), Agricultural intensification, economic identity, and shared invisibility in Amazonian peasantry: Caboclos and colonists in comparative perspective, Cult. Agric., 26, 1-24.

Brondizio, E. S. (2006), Landscapes of the past, footprints of the future: Historical ecology and the analysis of land use change in the Amazon, in Time and Complexity in Historical Ecology: Stuaies in the Neotropical Lowlands, edited by W. Balée and C. Erikson, pp. 365-405, Columbia Univ. Press, New York.

Brondizio, E. S. (2008), The Amazonian Caboclo and the Açai palm: Forest Farmers in the Global Market, Advances in Economic Botany Monograph Series, 403 pp., N. Y. Bot. Garden Press, Bronx, N. Y.

Brondizio, E. S. (2009), Forest resources, family networks and the municipal disconnect: Examining recurrent underdevelopment in the Amazon estuary, in Development and Conservation of the Amazonian Floodplains: The Decade Past and the Decade Ahead, edited by M. Pinedo-Vasquez et al., N. Y. Bot. Garden Press, Bronx, N. Y., in press.

Brondizio, E. S., and E. F. Moran (2008), Human dimensions of climate change: the vulnerability of small farmers in the Amazon, Philos. Trans. R. Soc. Ser. B. 363, 1803-1809doi:10.1098 rstb.2007.0025

Brondizio, E. S., and A. D. Siqueira (1997). From extractivist to forest farmers: Changing concepts of agricultural intensification and peasantry in the Amazon estuary. Res. Econ. Anthropol., 18 . 233-279.

Brondizio, E. S., S. D. McCracken, E. F. Moran, A. D. Siqueira. D. R. Nelson, and C. Rodriguez-Pedraza (2002), The colonist footprint: Toward a conceptual framework of land use and deforestation trajectories among small farmers in the Amazonian frontier, in Deforestation and Land Use in the Amazon. edited by C. H. Wood and R. Porro, pp. 133-161, University Press of Florida, Gainesville, FL

Brondizio, E. S., C. C. M. Safar, and A. D. Siqueira (2003), The urban market of Açai fruit (Euterpe oleracea Mart.) and rural land use change: Ethnographic insights into the role of price and land tenure constraining agricultural choices in the Amazon estuary, Urban Ecosyst., 6(1/2), 67-98.

Brookfield, H. (Ed.) (2001), Exploring Agrodiversity, Columbia Univ. Press, New York.

Browder, J. O., and B. J. Godfrey (1997), Rainforest Cities: Urbanization, Development, and Globalization of the Brazilian Amazon. Columbia Univ. Press, New York.

Browder, J. O., M. A. Pedlowski, R. Walker, R. H. Wynne, P. M Summers, A. Abad, N. Becerra-Cordoba. and J. Mil-Homens (2008), Revisiting theories of frontier expansion in the Brazilian Amazon: A survey of the colonist farming population in Rondônia's post-frontier, 1992-2002, World Dev., 36(8), 1469-1492.

Caldas, M., R. T. Walker, E. Arima, S. Perz. C. Wood, S. Aldrich. and C. Simmons (2007), Theorizing land use and land cover change: The peasant economy of Amazonian deforestation, Ann. Assoc. Am. Geogr., 97, 86-100

Caldas, M. M. (2008), Settlement formation and land cover and land use change: A case study in the Brazilian Amazon, Ph.D dissertation, Michigan State University, East Lansing. MI.

Campari, J. S. (2002), Challenging the turnover hypothesis of Amazon deforestation: Evidence from colonization projects in Brazil, Doctoral dissertation, The University of Texas at Austin, Austin.

Campos, M. T. (2006), From villains and victims to environmental activists: The case of Amazonian colonos, in Frontier Encounters: Indigenous Communities and Settlers in Asia and Latin America, edited by D. Geiger, International Work Group for Indigenous Affairs (IWGIA), Copenhagen, Denmark.

Campos M. T., and D. C. Nepstad (2006), Smallholders, the Amazon's new conservationists, Conserv. Biol., 20, 1553-1556.

Castellanet, C., and C. Jordan (2002), Participatory Action Research in Natural Resource Management: A Critique of the Method Based on Five Years' Experience in the Transamazonica Region of Brazil, Taylor and Francis, New York

Caviglia, J. L. (1999), Sustainable Agriculture in Brazil: Economic Development and Deforestation, New Horizons in Environmental Economics Series, Edward Elgar, Cheltenham, U. K.

Costa, F. A. (2008), Heterogeneidade Estrutural e Trajetórias Tecnológicas na Produção Rural da Amazônia: Delineamentos para Orientar Politicas de Desenvolvimento, in M. Batistella: E. F. Moran, D. S. Alves (Org.), Amazinia: Natureza e Sociedade em Transformação. 1st ed., vol. 1, pp. 137-180, Editora da Universidade de São Paulo, São Paulo. 
Costa. F. A., R. Hurtienne, and K. Kahwage (Orgs.) (2006), Inovação e Difusão Tecnológica da Agricultura Familiar na Amazónia, 1st ed, vol. 1, 278 pp., NAEA, Belém.

Costa, L. M. (2006), Comunicação \& Meio ambiente: A análise das campanhas de prevenção a incêndios florestais na Amazônia, Série Teses do Núcleo de Altos Estudos Amazônicos, Editora da Universidade Federal do Pará, Belém, Brazil.

Costa, N., (2004), O desmatamento na Amazônia e os pequenos agricultores, O Estado de São Paulo, Agência Estado, 6 May.

Costa, S. M., and E. S. Brondizio (2009), Cities along the floodplains of the Brazilian Amazon, in Development and Conservation of the Amazonian Floodplains: The Decade Past and the Decade Ahead, edited by M. Pinedo-Vasquez et al., N. Y. Bot. Garden Press, Bronx, N. Y., in press.

Costa, W. M., B. Becker, and D. S. Alves (Orgs.) (2007), Dimensões Humanas da Biosfera-Atmosfera da Amazônia, São Paulo: Editora da Universidade de São Paulo-Edusp.

D'Antona, A. O., L. K. Vanwey, and C. Hayashi (2006), Property size and land cover change in the Brazilian Amazon, Popul. Environ., 27(5-6), 373-396.

D'Antona, A. O., A. D. Cak, and L. K. VanWey (2008), Collecting sketch maps to understand property land use and land cover in large surveys, Field Methods, 20, 66-84.

Deadman, P.. D. Robinson, E. Moran, and E. Brondizio (2004), Colonists household decision making and land use change in the Amazon rainforest: An agent-based simulation, Environ. Plann. B Plann. Des., 31, 693-709.

DeCastro, F., A. D. Siqueira, E. S. Brondizio, and L. C. Ferreira (2006), Use and misuse of the concepts of tradition and property rights in the conservation of natural resources in the Atlantic Forest (Brazil), Ambient. Soc., 9(1), 23-39.

Dove, M. (1983), Theories of swidden agriculture, and the political economy of ignorance, Agroforestry Systems, 1, 85-99.

Durham, W. H. (1988), Political ecology and environmental destruction in Latin America, in The Social Causes of Environmental Destruction in Latin America, edited by M. Painter and W. H. Durham, pp. 249-264, Univ. of Michigan Press, Ann Arbor, MI.

Evans, T. P.. A. Manire, F. de Castro, E. Brondizio, and S. D. McCracken (2001), A dynamic model of household decisionmaking and parcel-level land cover change in the Eastern Amazon, Ecol. Modell., 143, 95-113.

FAO (2001), Global Forest Resource Assessment 2000, Food and Agriculture Organization, Rome, Italy.

FAO (2005), Global Forest Resource Assessment 2005, Food and Agriculture Organization, Rome, Italy.

Fearnside, P. M. (1986), Human Carrying Capacity of the Brazilian Rainforest, Columbia Univ. Press, New York.

Fearnside, P. M. (1993), Deforestation in the Brazilian Amazon: The effect of population and land tenure, Ambio, 22, 537-545.

Fearnside, P. M. (2001), Land-tenure issues as factors in environmental destruction in Brazilian Amazônia: The case of southern Pará, World Dev., 29(8), 1361-1372.

Folha Online (2008), Incra lidera lista dos 100 maiores desmatadores da Amazônia Legal, diz Meio Ambiente, By Renata Giraldi. (Available at http://wwwl.folha.uol.com.br/folha/brasil/ ult96u360405.shtml)
Futemma, C., and E. S. Brondizio (2003), Land reform and land use changes in the Lower Amazon: Implications to agricultural intensification, Hum. Ecol., 3I(3), 369-402.

Gentil, J. (1988), A juta na agricultura de várzea na area de Santarém-Médio Amazonas, Boletim do Museu Paraense Emílio Goeldi, 4(2), Série Antropologia, 118-199.

Guanziroli, C., A. Romeiro, A. M. Buainain, A. Sabbato, and G. Bittencourt (2001), Agricultura Familiar e Reforma Agrária no Século XXI, Garamond, Rio de Janeiro.

Hartshorn, G. S. (2006), Understanding tropical forests, BioScience, 56(3), 264-265.

Hecht, S. (1993), The logic of livestock and deforestation in Amazônia, Bioscience, 43(10), 687-695.

Hiraoka, M (1992), Caboclo and Ribereño resource management in Amazônia: A review, in Conservation of Neotropical Forests. Working from Traditional Resource Use, edited by K. Redford, and C. Padoch, pp. 134-157, Columbia Univ. Press, New York.

IBGE (1998), Censo Agropecuário 1995/1996-Brasil, 94 pp., Instituto Brasileiro de Geografia e Estatistica, Rio de Janeiro.

IBGE (2009a), Censo Agropecuário 2006-Brasil, Sistema SIDRA, Instituto Brasileiro de Geografia e Estatistica, Rio de Janeiro. (Available at http://www.sidra.ibge.gov.br)

IBGE (2009b), Censo agropecuário 2006: Agricultura Familiar, Primeiros Resultados, Brasil, Grandes Regiões e Unidades da Federação, report, 267 pp., Instituto Brasileiro de Geografi a e Estatistica, Rio de Janeiro. (Available at http://www.ibge. gov.br/home/estatistica/economia/agropecuaria/censoagro/ agri_familiar_2006/familia_censoagro2006.pdf)

INCRA (2000), Relatório de Atividades INCRA 30 Anos, Instituto Nacional de Colonizacao e Reforma Agraria. (Available at http://www.incra.gov.br/publicacoes/relatorios.html)

INCRA (2002), Balanço da Reforma Agrária e da Agricultura Familiar, Instituto Nacional de Colonizacao e Reforma Agraria. (Available at http://www.incra.gov.br/)

INCRA/FAO (2000), Relatório Projeto de Cooperação Técnica INCRA/FAO "Novo retrato da agricultura familiar: O Brasil redescoberto," G. A. Bittencourt, and Alberto Di Sabbatto (Coordenação), Instituto Nacional de Colonizacao e Reforma Agraria, Brasília.

INPE/PRODES (2003), Projeto PRODES e Coordenação-Geral de Observação da Terra, Instituto Nacional de Pesquisas Espaciais, São José dos Campos, Brazil. (Available at http://www. obt.inpe.br/prodes)

Jarvis, D., C. Padoch, and H. D. Cooper (Eds.) (2007), Managing Biodiversity in Agricultural Ecosystem.s, Columbia Univ. Press, New York.

Jones, D. W., V. H. Dale, J. J. Beauchamp, M. A. Pedlowski, and R. V. O'Neill (1995), Farming in Rondônia. Resour. Energy Econ., 17, 155-188.

Kaimowitz, D., and A. Angelsen (1998), Economic Models of Tropical Deforestation: A Review, Center for International Forestry Research, Bogor, Indonesia.

Lena, P., and A. Oliveira (Eds.) (1992). Amazônia: A Fronteira Agricola 20 Anos Depois, Edições CEJUP, Belém.

Lim, K., P. Deadman, E. Moran, E. Brondizio, and S. McCracken (2002), Agent-based simulations of househoid decision making 
and land use change in Altamira, Brazil, in Integrating Geographic Information Systems and Agent-Based Modeling Techniques for Simulating Social and Ecological Processes, edited by H. R. Gimblet, pp. 277-310, Oxford Univ. Press.

Ludewigs, T. (2006), Land-use decision making, uncertainty and effectiveness of land reform in acre, Brazilian Amazon, Doctoral dissertation, Indiana University, Bloomington.

Ludewigs, T., A. de O. D'Antona, E. S. Brondízio, and S. Hetrick (2009), Agrarian structure and land use change along the lifespan of three colonization areas in the Brazilian Amazon, World Dev., 37(9), 1348-1359.

Marquardt, K. A. (2008), Burning Changes: Action Research with Farmers and Swidden Agriculture in the Upper Amazon, Doctoral thesis No. 2008:42, Faculty of Natural Resources and Agricultural Sciences, Swedish Agricultural University (SLU), Uppsala, Sweden.

Marquette, C. (1998), Land use patterns among small farmer settlers in the northeastern Ecuadorian Amazon, Human Ecol., 26, 573-598.

McCracken, S. D., E. S. Brondizio, D. Nelson, E. F. Moran, A. D. Siqueira, and C. Rodriguez-Pedraza (1999), Remote sensing and GIS at farm property level: Demography and deforestation in the Brazilian Amazon, Photogramm. Eng. Remote Sens., 65, $1311-1320$

McCracken, S., A. D. Siqueira, E. F. Moran, and E. S. Brondizio (2002), Land use patterns on an agricultural frontier in Brazil; Insights and examples from a demographic perspective, in $\mathrm{De}$ forestation and Land Use in the Amazon, edited by C. Wood and R. Porro, pp. 162-192, Univ. Press of Florida, Gainesville.

Mena, C. (2001), Deforestation in the Napo Basin: Socioeconomic Factors, Spatial Patterns, and Metrics, Florida International University, Miami, FL

Mena, C., A. F. Barbieri, S. J. Walsh, C. M. Erlien, F. L. Holt, and R. E. Bilsborrow (2006a), Pressure on the Cuyabeno Wildlife Reserve: Development and land use/cover change in the Northern Ecuadorian Amazon, World Dev., 34, 1831-1849.

Mena, C., R. E. Bilsborrow, and M. E. McClain (2006b), Deforestation in the Napo Basin: Socioeconomic factors, spatial patterns, and metrics, Environ. Manage., 37, 802-815.

Moran, E. F. (1981), Developing the Amazon, Indiana Univ. Press, Bloomington, IN

Moran, E. F. (1990), Private and public colonization schemes in Amazônia, in The Future of Amazônia: Destruction or Sustainable Development?, edited by D. Goodman, and A. Hall, St. Martin's Press, New York.

Moran, E. F., E. Brondizio, and S. McCracken (2002), Trajectories of land use: Soils, succession, and crop choice, in Deforestation and Land Use in the Amazon, edited by C. H. Wood, and R. Porro, pp. 193-217, Univ. of Florida Press, Gainesville, FL.

Moran, E., E. Brondizio, and L. VanWey (2005), Population and Environment in Amazonia: Landscape and Household Dynamics, Population, Land Use, and Environment, edited by B. Entwisle and P. Stern, pp. 106-134, The National Academies Press, Washington, D. C.

Moran, E. F., E. S. Brondizio, and M. Batistella (2008), Trajetórias de Desmatamento e Uso da Terra na Amazonia Brasileira: Uma
Análise Multiescalar, in Amazônia: Natureza e Sociedade em Transformação, edited by M. Batistella, E. F. Moran, and D. S. Alves, pp. 137-180, EDUSP, São Paulo.

Muchagata, M. (1997), Forests and people: the role of forest production in frontier farming systems in Eastern Amazônia, Development Studies Occasional Paper 36, 79 pp., University of East Anglia, School of Development Studies, Norwich, England.

Murphy, L. L. (2001), Colonist farm income, off-farm work, cattle, and differentiation in Ecuador's northern Amazon, Hum. Organ., 60(1), 67-79.

Myers, N. (1990), The biodiversity challenge: Expanded hot-spots analysis, Environmentalist, 10, 243-256.

Nepstad, D., D. McGrath, A. Alencar, A. C. Barros, M. Carvalho, and M. d. C. Vera Diaz (2002), Frontier governance in Amazônia, Science, 295, 629-631.

Netting, R. M. (1993), Smallholders, Householders: Farm Families and the Ecology of Intensive, Sustainable Agriculture, Stanford Univ. Press, Stanford.

OESP (2008a), Crédito Fácil do Governo Contribui com o Desmantamento na Amazônia, O Estado de São Paulo.

OESP (2008b), TCU diz que Pequenos Produtores Respondem por $18 \%$ do Desmatamento, O Estado de São Paulo.

Orme, C. D. L., et al. (2005), Global hotspots of species richness are not congruent with endemism or threat, Nature, 436 , 1016-1019

Ozório de Almeida, A. L., and J. S. Campari (1995), Sustainable Settlement in the Brazilian Amazon, Oxford Univ. Press, New York.

Padoch, C., and M. Pinedo-Vasquez (2006), Concurrent activities and invisible technologies: An example of timber management in Amazônia, in Human Impacts on Amazônia: The Role of Traditional Ecological Knowledge in Conservation and Development, edited by D. Posey, and M. Ballick, Columbia Univ. Press, New York.

Padoch, C., E. S. Brondizio, S. Costa, M. Pinedo-Vasquez, R. Sears, and A. Siqueira (2008), Urban forest and rural cities: Multi-sited households, consumption patterns, and forest resources in Amazonia, Ecol. Soc., 13(2), 2. (Available at http://www.ecologyandsociety.org/voll3/iss2/art2/)

Palm, C., S. Vosti, P. Sanchez, and P. Erickson (Eds.) (2005), Slash-and-Burn Agriculture: The Search for Alternatives, Columbia Univ. Press, New York.

Pan, W. K., and R. E. Bilsborrow (2005), The use of a multilevel statistical model to analyze factors influencing land use: A study of the Ecuadorian Amazon, Global Planet. Change, 47, 232-252.

Pan, W. K., S. J. Walsh, R. E. Bilsborrow, B. G. Frizzelle, C. M. Erlien, and F. Baquero (2004), Farm-level models of spatial patterns of land use and land cover dynamics in the Ecuadorian Amazon, Agric. Ecosyst. Environ., 101, 117-134.

Pan, W. K., D. Carr, A. Barbieri, R. Bilsborrow, and C. Suchindran (2007), Forest clearing in the Ecuadorian Amazon: A study of patterns over space and time, Popul. Res. Policy Rev., 26(5-6), 635-659, doi:10.1007/s11113-007-9045-6.

Peroni, N., P. Y. Kageyama, and A. Begossi (2007), Molecular differentiation, diversity, and folk classification of "sweet" and

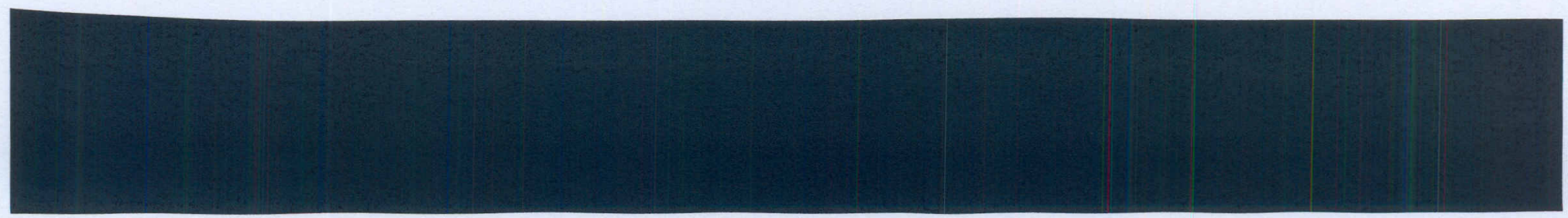


"bitter" cassava in Caiçara and Caboclo management systems (Brazil), Genetic Resources and Crop Evolution, 54(6), 1333-1349.

Perz, S. G. (2001), Household demographic factors as life cycle determinants of land use in the Amazon, Popul. Res. Policy Rev., 20, 159-186.

Perz, S. G., and R. Walker (2002), Household life cycles and secondary forest cover among small farm colonists in the Amazon, World Dev., 30, 1009-1027.

Pichón, F. (1997), Settler households and land-use patterns in the Amazon frontier: Farm-level evidence from Ecuador, World Dev., 25, 67-91.

Pichon, F., and R. E. Bilsborrow (1999), Land use systems, deforestation and demographic factors in the humid tropics: Farmlevel evidence from Ecuador, in Population and Deforestation in the Humid Tropics, edited by R. Bilsborrow and D. Hogan, pp. 175-207, International Union for the Scientific Study of Population, Liege, Belgium.

Pichón, F., C. Marquette, L. Murphy, and R. E. Bilsborrow (2002), Endogenous patterns and processes of settler land use and forest change in the Ecuadorian Amazon, in Deforestation and Land Use in the Amazon, edited by C. Wood and R. Porro, Univ. Press of Florida, Gainesville, FL.

Pinedo-Vasquez, M., and C. Padoch (2009), Urban, rural and inbetween: Multi-sited households, mobility and resource management in the Amazon floodplain, in Mobility and Migration in Indigenous Amazônia: Contemporary Ethnoecological Perspectives, edited by M. N. Alexiades, Berghahn, Oxford, U. K., in press.

Pinedo-Vasquez, M., D. J. Zarin, K. Coffey, C. Padoch, and F. Rabelo (2001), Post-boom logging in Amazônia, Hum. Ecol., 29(2), 219-239.

Pinedo-Vasquez, M., C. Padoch, D. McGrath, and T. XimenesPonte (2002), Biodiversity as a product of smallholder response to change in Amazônia, in Cultivating Biodiversity: Understanding, Analysing and Using Agricultural Diversity, edited by $\mathrm{H}$. Brookfield et al., pp. 167-178, ITDG, London, U. K.

Pinedo-Vasquez, M., D. McGrath, and T. Ximenes (2003), Brazil (Amazônia), in Agrodiversity: Learning from Farmers Across the World, edited by H. Brookfield, H. Parsons, and M. Brookfield, pp. 43-78, UNU Press, Tokyo, Japan.

Primack, R. B., and R. T. Corlett (2005), Tropical Rain Forests: An Ecological and Biogeographical Comparison, Blackwell, New York.

Rerkasem, K., and M. Pinedo-Vasquez (2007), Diversity and innovation in smallholder systems in response to environmental and economic changes, in Managing Biodiversity in Agricultural Ecosystems, edited by D. Jarvis, C. Padoch, and H. D. Cooper, Columbia Univ. Press, New York.

Roseberry, W. (1993), Beyond the agrarian question in Latin America, in Confronting Historical Paradigms, edited by F. Cooper et al., pp. 318-370, Univ. of Wisconsin Press, Madison.

Santos, C., and J. P. Messina (2008), Multi-sensor data fusion for modeling A frican palm in the Ecuadorian Amazon, Photogramm. Eng. Remote Sens., 74(2), Special Issue on Remote Sensing Data Fusion, 711-723.
Schmink, M., and C. Wood (1992), Contested Frontiers in Amazônia, Columbia Univ. Press, New York.

Sierra, R. (2000), Dynamics and patterns of deforestation in the Western Amazon: The Napo deforestation front, 1986-1996, Appl. Geogr., 20, 1-16.

Silva-Forsberg, M. C., and P. Fearnside (1997), Brazilian Amazonian caboclo agriculture: Effect of fallow period on maize yield, For. Ecol. Manage., 97(3), 283-291. doi:10.1016/S0378$1127(97) 00070-4$

Simons, C. S. (2005), Territorializing land conflict: Space, place, and contentious politics in the Brazilian Amazon, Geojournal, 64, 307-317, doi 10.1007/s10708-005-5809-x.

Siqueira, A. D., S. D. McCracken, E. Brondizio, and E. F. Moran (2003), Women and work in a Brazilian agricultural frontier, in Gender at Work in Economic Life, edited by G. Clark, pp. 243 267, Altimira Press, Lanham, Md.

Siqueira, A. D., A. O. D'Antona, M. F. Dantona, and E. F. Moran (2007), Embodied decisions: Reversible and irreversible contraceptive methods among rural women in the Brazilian Amazon, Hum. Organ., 66(2), 185-195.

Smith, N. (1982), Rainforest Corridors: The Transamazon Colonization Scheme, Univ. of California Press, Berkeley.

Smith, N., R. Vásquez, and W. Wust (2007), Amazon River Fruits. Flavors for Conservation, Amazon Conservation Association (ACA), Miss. Bot. Garden Press, St. Louis, Miss.

Smith, N. J. H., I. C. Falesi, P. T. Alvin, and E. A. S. Serrao (1996), Agroforestry trajectories among smallholders in the Brazilian Amazon: Innovations and resiliency in pioneer and older settled areas, Ecol. Econ., 18, 15-27.

Sorrensen, C. (2004), Contributions of fire use study to land use/ cover change frameworks: understanding landscape change in agricultural frontiers, Hum. Ecol., 32(4), 395-419.

Sydenstricker Neto, J., and S. A. Vosti (1993), Household size, sex composition, and land use in tropic moist forests: Evidence from the Machadinho Colonization Project, Rondonia, Brazil, paper presented at Annual Meeting, Popul. Soc. of Am., Cincinnati, Ohio.

Tamariz, M. E., and X. Villaverde (1997), Diagnóstico de la Tenencia de la Tierra en las Provincias de Sucumbios y Napo, FEPP, Quito, Ecuador.

Toniolo, A. (2004), The role of land tenure in the occurrence of accidental fires in the Amazon Region: Case studies from the National Forest of Tapajós, Pará, Brazil, Doctoral dissertation, Indiana University, Bloomington.

Tura, L. R., and F. de A. Costa (Eds.) (2000), Campesinato e Estado na Amazônia: Impactos do FNO no Pará, Brasília Jurídical FASE, Brasilia, Brazil.

Uquillas, J. (1984), Colonization and spontaneous settlement in the Ecuadorian Amazon, in Frontier Expansion in Amazônia, edited by M. Schmink and C. Wood, pp. 261-284, Univ. of Florida Press, Gainesville, FL.

VanWey, L., A. O. D'Antona, and E. S. Brondizio (2007), Household demographic change and land use/land cover change in the Brazilian Amazon, Popul. Environ., 28, 163-185. 
Vosti, S. A., E. M. Braz, C. L. Carpentier, and M. V. N. Oliveira (2003), Rights to forest products, deforestation and smallholder income: Evidence from western Brazilian Amazon, World Dev., 31(11), 1889-1901.

Walker, R. T. (2003), Mapping process to pattern in the landscape change of the Amazonian frontier, Ann. Assoc. Am. Geogr., 93, 376-398.

Walker, R. T., E. F. Moran, and L. Anselin (2000), Deforestation and cattle ranching in the Brazilian Amazon: External capital and household process, World Dev., 8, 683-699.

Walker, R. T., S. Perz, M. Caldas, and L. G. T. Silva (2002), Land use and land cover change in forest frontier: The role of household life cycles, Int. Reg. Sci. Rev., 25, 169-199.

Walsh, S. J., J. P. Messina, K. Crews-Meyers, R. E. Bilsborrow, and W. K. Pan (2002), Characterizing and modeling patterns of deforestation and agricultural extensification in the Ecuadorian Amazon, in Linking People, Place, and Policy: A GIScience Approach, edited by S. J. Walsh and K. Crews-Meyers, pp. $187-$ 214, Springer, Boston, MA

Winkerprins, A. (2006), Jute in the Lower Amazon, J. Hist. Geogr., 32(4), 818-838.

WinklerPrins, A. M. G. A. (2002), Recent seasonal floodplainupland migration along the lower Amazon River, Brazil, Geogr. Rev., 92(3), 415-431.

Wood, C., and M. Schmink (1979), Blaming the victim: Small farmer production in an Amazon Colonization Project, Stud. Third World Soc., 7, 77-93.

Wood, C. H., and R. Porro (Eds.) (2002), Deforestation and Land Use in the Amazon, Univ. of Florida Press, Gainsville, FL.

Yamada, M. (1999), Japanese immigrant agroforestry in the Brazilian Amazon: A case study of sustainable rural development in the tropics, Doctoral dissertation, Univ. of Florida, Gainesville, FL.

Zarin, D., J. R. Alavalapati, F. E. Putz, and M. Schmink (Eds.) (2004), Working Forests in the Neotropics: Conservation through Sustainable Management?, Columbia Univ. Press, New York.

M. Batistella, Embrapa Monitoriamento por Satélite, Av. Soldado Passarinho 303, Fazenda Chapadão, Campinas, SP CEP 13070-115, Brasil.

R. Bilsborrow, Biostatistics Department and Carolina Population Center, University of North Carolina, Chapel Hill, NC 275162524, USA.

E. S. Brondizio and E. Moran, Department of Anthropology, Indiana University, 701 E. Kirkwood, Student Building 130, Bloomington, IN 47405, USA. (ebrondiz@indiana.edu)

A. D. Cak, School of Public and Environmental Affairs, Indiana University, Student Building 331, Bloomington, IN 47405, USA.

M. Caldas, Department of Geography, Kansas State University, 118 Seaton Hall, Manhattan, KS 66502, USA.

C. T. Futemma, Campus de Sorocaba, Rodovia João Leme dos Santos, km-110, SP-264, Bairro Itinga, Sorocaba, SP CEP $18052-$ 780, Brazil.

T. Ludewigs, Centro de Desenuolvimento Sustentável, UnBCampus, Universitário Darch Ribeiro-Gleba A, Bloco C-Av. L3 Norte, Asa Norte, Brasilia DF, CEP 70904-970, Brazil.

C. Mena, Colegio de Ciencias Biologicas y Ambientales, Universidad San Francisco de Quito, Campus Cumyaba Diego de Robles S/N, Quito, Ecuador. 